\title{
Pallada- and platinacycle complexes of phosphorus ylides; Synthesis, X-ray characterization, theoretical and electrochemical studies and application of Pd(II) complexes as catalyst in Suzuki-Miyaura coupling reaction
}

Seyyed Javad Sabounchei ${ }^{\mathrm{a}^{*}}$, Asieh Sedghi ${ }^{\mathrm{a}}$, Ali Hashemi ${ }^{\mathrm{a}}$, Marjan Hosseinzadeh ${ }^{\mathrm{a}}$, Mehdi Bayat $^{\mathrm{a}}$, Robert W. Gable ${ }^{\mathrm{b}}$

${ }^{a}$ Faculty of Chemistry, Bu-Ali Sina University, Hamedan,65174, Iran

${ }^{\mathrm{b}}$ School of Chemistry, University of Melbourne, Victoria, 3010, Australia

Abstract: The new unsymmetrical phosphonium salts $\left[\mathrm{Ph}_{2} \mathrm{PCH}_{2} \mathrm{PPh}_{2} \mathrm{CH}_{2} \mathrm{C}(\mathrm{O}) \mathrm{C}_{6} \mathrm{H}_{4} \mathrm{R}\right] \mathrm{Br}(\mathrm{R}=m$ $\operatorname{Br}\left(\mathbf{S}_{1}\right)$ and $\left.p-\mathrm{CN}\left(\mathbf{S}_{2}\right)\right)$ were synthesized in the reaction of 1,1-bis(diphenylphosphino)methane $(\mathrm{dppm})$ and $\mathrm{BrCH}_{2} \mathrm{C}(\mathrm{O}) \mathrm{C}_{6} \mathrm{H}_{4} \mathrm{R}(\mathrm{R}=m-\mathrm{Br}$ and $p$-CN) ketones, respectively. Further treatment with $\mathrm{NEt}_{3}$ gave the $\alpha$-keto stabilized phosphorus ylides $\mathrm{Ph}_{2} \mathrm{PCH}_{2} \mathrm{PPh}_{2} \mathrm{C}(\mathrm{H}) \mathrm{C}(\mathrm{O}) \mathrm{C}_{6} \mathrm{H}_{4} \mathrm{R}(\mathrm{R}=m$ - $\mathrm{Br}$ $\left(\mathbf{Y}_{1}\right)$ and $\left.p-\mathrm{CN}\left(\mathbf{Y}_{2}\right)\right)$. These ligands were reacted with $\left[\mathrm{MCl}_{2}(\mathrm{cod})\right](\mathrm{M}=\mathrm{Pd}$ and $\mathrm{Pt}$; cod= 1,5cyclooctadiene) to give the pallada- and platinacycle complexes $\left[\mathrm{MCl}_{2}\left(\mathrm{Ph}_{2} \mathrm{PCH}_{2} \mathrm{PPh}_{2} \mathrm{C}(\mathrm{H}) \mathrm{C}(\mathrm{O}) \mathrm{C}_{6} \mathrm{H}_{4} \mathrm{R}\right)\right](\mathrm{M}=\mathrm{Pd}, \mathrm{R}=m-\mathrm{Br}(3) ; \mathrm{R}=p-\mathrm{CN}(\mathbf{4})$ and $\mathrm{M}=\mathrm{Pt}, \mathrm{R}=m-\mathrm{Br}$ (5); $\mathrm{R}=p$-CN (6)). Cyclic voltammetry, elemental analysis, IR and $\mathrm{NMR}\left({ }^{1} \mathrm{H},{ }^{13} \mathrm{C}\right.$ and $\left.{ }^{31} \mathrm{P}\right)$ spectroscopic methods were used for characterization of the obtained compounds. Further, the structure of complexes $\mathbf{3}$ and $\mathbf{4}$ were characterized crystallographically. Palladacycles $\mathbf{3}$ and $\mathbf{4}$ were proved to be excellent catalysts for the Suzuki-Miyaura coupling reactions of various aryl chlorides and arylboronic acids in mixed $\mathrm{DMF} / \mathrm{H}_{2} \mathrm{O}$ media. Also, the bonding situations between

\footnotetext{
*Corresponding author. E-mail address: jsabounchei@yahoo.co.uk (S.J. Sabounchei).

This is the author manuscript accepted for publication and has undergone full peer review but has not been through the copyediting, typesetting, pagination and proofreading process, which may lead to differences between this version and the Version of Record. Please cite this article as doi: $10.1002 /$ aoc.3850
} 
two interacted fragments $\left[\mathrm{PtCl}_{2}\right]$ and $\mathbf{Y}_{\mathbf{1}}$ and $\mathbf{Y}_{2}$ ligands in platinacycles $\mathbf{5}$ and $\mathbf{6}$ were investigated based on DFT method by using NBO, EDA and ETS-NOCV analysis.

Keywords: Pallada- and platinacycle; Phosphorus ylide; Theoretical studies; Suzuki-Miyaura reaction; DFT method.

\section{Introduction}

Stabilized phosphorus ylides are an important class of compounds that have attracted considerable interest because of their value for a variety of industrial, biological and chemical synthetic uses. ${ }^{[1-4]}$ Unsymmetrical $\alpha$-keto stabilized ylides derived from diphosphines have shown more useful application in organometallic chemistry due to their ambidentate character as ligands ${ }^{[5-9]}$ Furthermore, they are valuable key intermediates in metal-mediated organic synthesis. ${ }^{[10,11]}$ The coordination behavior of these compounds towards several metal ions has been studied and it was found that phosphorus ylides can coordinate to metal ions in three modes as depicted in Chart 1: monodentate (or unidentate), bidentate (or chelating) and bridging (or bridging bidentate) modes.

\section{Chart 1 here}

When a metal ion such as $\mathrm{Hg}(\mathrm{II})$ or $\mathrm{Ag}(\mathrm{I})$ interacts only with the free $\mathrm{P}$ atom of phosphorus group, the coordination structure is regarded as monodentate mode. ${ }^{[12,13]}$ If the coordination of ylide occurs through the $\mathrm{C} \alpha$ atom of ylidic group, it was also categorized in above mentioned coordination mode. ${ }^{[14]}$ Though the ylides can coordinate to the metal ions through the $\mathrm{O}$ atoms of 
carbonyl group, there are few examples of O-coordinated ylides which are known. Some of these complexes include a hard and very oxophilic metal center, such as $\operatorname{Sn}(\mathrm{IV}){ }^{[15]}$ or group 4 metal ions with high oxidation number e.g. $\mathrm{Ti}(\mathrm{IV}), \mathrm{Zr}(\mathrm{IV})$ and $\mathrm{Hf}(\mathrm{IV}) .{ }^{[16]}$

Bidentate (or chelating) coordination mode occurs when a metal ion (for example Pd(II) or $\mathrm{Cu}(\mathrm{I})$ ) interacts with two $\mathrm{P}$ and $\mathrm{C}$ atoms of ylidic group to give the $\mathrm{P}, \mathrm{C}$-chelated complexes. ${ }^{[17}$, ${ }^{18]}$ Although the P, O-chelated coordination mode was also possible, but to the best of our knowledge, it was only observed in the $\operatorname{Pd}(\mathrm{II})$ complexes of a mixed phosphine- $\beta$ ketophosphorus ylide. ${ }^{[19]}$ Finally, the bridging coordination mode can be seen when a metal ion bound to one phosphorus ylide through $\mathrm{P}$ atom and another metal ion bound to the $\mathrm{C} \alpha$ or $\mathrm{O}$ atom. ${ }^{[20]}$ The investigation of reactivity and coordination chemistry of carbonyl stabilized ylides is an important research field of our group. ${ }^{[12-14,17,18]}$ Recently, we reported the synthesis of palladium(II) complexes containing such phosphorus ylides. ${ }^{[17,21-23]}$ We aim to expand the scope of these complexes to the new platinacycle complexes of bidentate phosphorus ylides.

Pd(II) complexes bearing phosphine groups have been extensively applied as efficient catalysts in some cross-coupling reactions. ${ }^{[21-27]}$ Specifically, the Suzuki-Miyaura reaction which emerged as the most important and reliable method for construction of functionalized biaryl, have been catalysed with the P, C-chelated Pd(II) complexes of such phosphorus ylides. ${ }^{[28-31]}$ Recently, it was reported a variety of catalytic systems for the Suzuki-Miyaura coupling reaction using mixed aqueous media. ${ }^{[31-34]}$ Application of palladacycle complexes of phosphorus ylides as efficient catalyst in Suzuki-Miyaura coupling reactions of aryl chlorides under relatively mild 
experimental conditions is one of the purposes of this work. Although there is no X-ray structure available in this report to prove the molecular structures of platinacycles, however DFT theoretical studies by using NBO, EDA and ETS-NOCV analysis have been performed to elucidate the physical and chemical nature of interactions. We have now focused our attention to the synthesis, spectroscopic (IR and NMR) and electrochemical study of the new pallada- and platinacycles complexes of phosphorus ylide.

\section{Experimental}

\subsection{Materials and methods}

The synthesis reaction of phosphorus ylides and their $\mathrm{Pd} / \mathrm{Pt}(\mathrm{II})$ complexes was carried out under dry nitrogen using standard Schlenk techniques. 2,3'-dibromoacetophenone, 2-bromo-4'cyanoacetophenone and dppm were purchased from commercial sources and used without further purification. $\left[\mathrm{MCl}_{2}(\operatorname{cod})\right](\mathrm{M}=\mathrm{Pd}$ and $\mathrm{Pt})$ complexes were prepared according to the published procedures. ${ }^{[35]}$ Toluene and chloroform were used as reagent grade and dried over $\mathrm{Na} /$ benzophenone and $\mathrm{P}_{2} \mathrm{O}_{5}$, respectively. Elemental analysis was performed on a Leco, CHNS932 apparatus. The NMR spectra $\left({ }^{1} \mathrm{H},{ }^{13} \mathrm{C}\right.$ and $\left.{ }^{31} \mathrm{P}\right)$ were recorded on BrukerAvance $400 \mathrm{MHz}$, $250 \mathrm{MHz}$ and Jeol $90 \mathrm{MHz}$ spectrometers in $\mathrm{CDCl}_{3}$ or DMSO- $\mathrm{d}_{6}$ as solvents at $25^{\circ} \mathrm{C}$. IR spectra 
were recorded on $\mathrm{KBr}$ pellets using a Shimadzu 435-U 04 spectrophotometer in the region of 4000-400 $\mathrm{cm}^{-1}$. Cyclic voltammetry was performed using an Autolab model PGSTAT 20 potentiostat/galvanostat. The working electrode used in the voltammetry experiments was a glassy carbon disc $\left(1.8 \mathrm{~mm}^{2}\right.$ area $)$, and a platinum wire was used as the counter electrode. The working electrode potentials were measured versus the $\mathrm{Ag} / \mathrm{AgCl}$ electrode (all electrodes were purchased from AZAR Electrodes co.).

\subsection{Synthesis of phosphonium salts}

General procedure: A chloroform solution $(5 \mathrm{~mL})$ of dppm $(0.5 \mathrm{mmol})$ and ketone $(0.55$ mmol) was stirred at room temperature for $15 \mathrm{~h}$. The resulting solution was concentrated to $c a .3$ $\mathrm{mL}$ under reduced pressure and then treated with diethyl ether to precipitate phosphonium salt.

2.2.1. Data for phosphonium salt $\left[\mathrm{Ph}_{2} \mathrm{PCH}_{2} \mathbf{P P h}_{2} \mathrm{CH}_{2} \mathrm{C}(\mathrm{O}) \mathrm{C}_{6} \mathrm{H}_{4}-m-\mathrm{Br}\right] \mathrm{Br}\left(\mathrm{S}_{1}\right)$. Yield: 0.314 g (94\%). Anal. Calcd for $\mathrm{C}_{33} \mathrm{H}_{28} \mathrm{Br}_{2} \mathrm{OP}_{2}(\%)$ : C, 59.84; H, 4.26. Found: C, 59.77; H, 4.22. M.p. 196- $198{ }^{\circ} \mathrm{C}$. Selected IR absorption in $\mathrm{KBr}\left(\mathrm{cm}^{-1}\right) v(\mathrm{CO}): 1676 .{ }^{1} \mathrm{H}$ NMR $\left(89.6 \mathrm{MHz}, \mathrm{CDCl}_{3}\right)$ $\delta_{\mathrm{H}}(\mathrm{ppm}): 4.31\left(\mathrm{~d}, 2 \mathrm{H}, \mathrm{PCH}_{2} \mathrm{P},{ }^{2} \mathrm{~J}_{\mathrm{P}-\mathrm{H}}=12.23\right), 5.96\left(\mathrm{~d}, 2 \mathrm{H}, \mathrm{PCH}_{2} \mathrm{CO},{ }^{2} \mathrm{~J}_{\mathrm{P}-\mathrm{H}}=12.81\right), 7.30-7.99$ $(\mathrm{m}, 24 \mathrm{H}, \mathrm{Ph}) .{ }^{31} \mathrm{P}$ NMR $\left(36.26 \mathrm{MHz}, \mathrm{CDCl}_{3}\right) \delta_{\mathrm{P}}(\mathrm{ppm}):-28.67\left(\mathrm{~d}, \mathrm{PPh}_{2},{ }^{2} \mathrm{~J}_{\mathrm{P}-\mathrm{P}}=62.37 \mathrm{~Hz}\right), 21.12$ $\left(\mathrm{d}, \mathrm{PCH}_{2} \mathrm{CO},{ }^{2} \mathrm{~J}_{\mathrm{P}-\mathrm{P}}=63.85 \mathrm{~Hz}\right) \cdot{ }^{13} \mathrm{C} \mathrm{NMR}\left(62.90 \mathrm{MHz}, \mathrm{CDCl}_{3}\right) \delta_{\mathrm{C}}(\mathrm{ppm}): 191.40\left(\mathrm{~d}, \mathrm{CO},{ }^{2} \mathrm{~J}_{\mathrm{P}-\mathrm{C}}=\right.$ 5.85), 117.15-151.83 (m, Ph), $37.38\left(\mathrm{~d}, \mathrm{CH}_{2},{ }^{1} \mathrm{~J}_{\mathrm{P}-\mathrm{C}}=60.38\right), 21.95\left(\mathrm{dd}, \mathrm{CH}_{2},{ }^{1} \mathrm{~J}_{\mathrm{P}-\mathrm{C}}=51.96\right.$, 34.47). 
2.2.2. Data for phosphonium salt $\left[\mathrm{Ph}_{2} \mathrm{PCH}_{2} \mathrm{PPh}_{2} \mathrm{CH}_{2} \mathbf{C}(\mathbf{O}) \mathbf{C}_{6} \mathbf{H}_{4}-p-\mathrm{CN}\right] \mathrm{Br}\left(\mathbf{S}_{2}\right)$. Yield: 0.301 g (98\%). Anal. Calcd for $\mathrm{C}_{34} \mathrm{H}_{28} \mathrm{BrNOP}_{2}(\%)$ : C, 67.12; H, 4.64; N, 2.30. Found: C, 67.01; H, 4.51; N, 2.41. M.p. $191-194{ }^{\circ} \mathrm{C}$. Selected IR absorption in $\mathrm{KBr}\left(\mathrm{cm}^{-1}\right) v(\mathrm{CO}): 1682 .{ }^{1} \mathrm{H}$ NMR $\left(250.13 \mathrm{MHz}, \mathrm{CDCl}_{3}\right) \delta_{\mathrm{H}}(\mathrm{ppm}): 4.25\left(\mathrm{~d}, 2 \mathrm{H}, \mathrm{PCH}_{2} \mathrm{P},{ }^{2} \mathrm{~J}_{\mathrm{P}-\mathrm{H}}=14.75\right), 6.08\left(\mathrm{~d}, 2 \mathrm{H}, \mathrm{PCH}_{2} \mathrm{CO},{ }^{2} \mathrm{~J}_{\mathrm{P}-\mathrm{H}}\right.$ $=12.75), 7.24-7.89(\mathrm{~m}, 24 \mathrm{H}, \mathrm{Ph}) .{ }^{31} \mathrm{P}$ NMR $\left(202.45 \mathrm{MHz}, \mathrm{CDCl}_{3}\right) \delta_{\mathrm{P}}(\mathrm{ppm}):-25.83\left(\mathrm{~d}, \mathrm{PPh}_{2},{ }^{2} \mathrm{~J}_{\mathrm{P}-}\right.$ $\mathrm{P}=64.17 \mathrm{~Hz}), 24.41\left(\mathrm{~d}, \mathrm{PCH}_{2} \mathrm{CO},{ }^{2} \mathrm{~J}_{\mathrm{P}-\mathrm{P}}=63.57 \mathrm{~Hz}\right) .{ }^{13} \mathrm{C} \mathrm{NMR}\left(62.90 \mathrm{MHz}, \mathrm{CDCl}_{3}\right) \delta_{\mathrm{C}}(\mathrm{ppm})$ : $191.66(\mathrm{~s}, \mathrm{CO}), 117.13-137.95(\mathrm{~m}, \mathrm{Ph}), 36.90\left(\mathrm{~d}, \mathrm{CH},{ }^{1} \mathrm{~J}_{\mathrm{P}-\mathrm{C}}=62.40\right), 21.93\left(\mathrm{dd}, \mathrm{CH}_{2},{ }^{1} \mathrm{~J}_{\mathrm{P}-\mathrm{C}}=\right.$ $70.86,35.29)$.

\subsection{Synthesis of phosphorus ylides}

General procedure: The resulted phosphonium salt was further treated with triethyl amine (0.5 $\mathrm{mL}$ ) in dry toluene. The triethyl amine hydrobromide was filtered off. Concentration of the toluene solution to $c a .3 \mathrm{~mL}$ and subsequent addition of petroleum ether $(20 \mathrm{~mL})$ resulted in the precipitation of phosphorus ylide.

2.3.1. Data for phosphorus ylide $\mathrm{Ph}_{2} \mathrm{PCH}_{2} \mathrm{PPh}_{2} \mathbf{C}(\mathrm{H}) \mathrm{C}(\mathrm{O}) \mathrm{C}_{6} \mathrm{H}_{4}-m-\mathrm{Br}\left(\mathrm{Y}_{1}\right)$. Yield: $0.234 \mathrm{~g}$ (80\%). Anal. Calc. for $\mathrm{C}_{33} \mathrm{H}_{27} \mathrm{BrOP}_{2}(\%)$ : C, 68.17; H, 4.68 Found: C, 68.11; H, 4.59. M.p. 157$160{ }^{\circ} \mathrm{C}$. Selected IR absorption in $\mathrm{KBr}\left(\mathrm{cm}^{-1}\right) v(\mathrm{CO}): 1572 .{ }^{1} \mathrm{H}$ NMR $\left(89.60 \mathrm{MHz}, \mathrm{CDCl}_{3}\right) \delta_{\mathrm{H}}$ (ppm): $3.64\left(\mathrm{~d}, 2 \mathrm{H}, \mathrm{PCH}_{2} \mathrm{P},{ }^{2} \mathrm{~J}_{\mathrm{P}-\mathrm{H}}=14.06 \mathrm{~Hz}\right), 4.31(\mathrm{br}, 1 \mathrm{H}, \mathrm{PCH}), 6.70-7.91(\mathrm{~m}, 24 \mathrm{H}, \mathrm{Ph}) .{ }^{31} \mathrm{P}$ NMR (36.26 MHz, $\left.\mathrm{CDCl}_{3}\right) \delta_{\mathrm{P}}(\mathrm{ppm}):-26.82\left(\mathrm{~d}, \mathrm{PPh}_{2},{ }^{2} \mathrm{~J}_{\mathrm{P}-\mathrm{P}}=66.71 \mathrm{~Hz}\right), 14.53\left(\mathrm{~d}, \mathrm{PCH},{ }^{2} \mathrm{JP}_{\mathrm{P}-\mathrm{P}}=\right.$ $65.99 \mathrm{~Hz} .{ }^{13} \mathrm{C}$ NMR (62.90 MHz, $\left.\mathrm{CDCl}_{3}\right) \delta_{\mathrm{C}}(\mathrm{ppm}): 183.07$ (s, CO), 121.99-143.22 (m, Ph), $50.62\left(\mathrm{~d}, \mathrm{CH},{ }^{1} \mathrm{~J}_{\mathrm{P}-\mathrm{C}}=111.39\right), 24.42\left(\mathrm{dd}, \mathrm{CH}_{2},{ }^{1} \mathrm{~J}_{\mathrm{P}-\mathrm{C}}=57.86,32.07\right)$. 
2.3.2. Data for phosphorus ylide $\mathbf{P h}_{2} \mathbf{P C H}_{2} \mathbf{P P h}_{2} \mathbf{C}(\mathbf{H}) \mathbf{C}(\mathbf{O}) \mathbf{C}_{6} \mathbf{H}_{4}-p-\mathrm{CN}\left(\mathbf{Y}_{2}\right)$. Yield: $0.194 \mathrm{~g}$ (73\%). Anal. Calc. for $\mathrm{C}_{34} \mathrm{H}_{27} \mathrm{NOP}_{2}(\%)$ : C, 77.41; H, 5.16; N, 2.66. Found: $\mathrm{C}, 77.38 ; \mathrm{H}, 5.12 ; \mathrm{N}$, 2.72. M.p. $149-153{ }^{\circ} \mathrm{C}$. Selected IR absorption in $\mathrm{KBr}\left(\mathrm{cm}^{-1}\right) v(\mathrm{CO}): 1572 .{ }^{1} \mathrm{H}$ NMR $(500.13$ $\left.\mathrm{MHz}, \mathrm{CDCl}_{3}\right) \delta_{\mathrm{H}}(\mathrm{ppm}): 3.68\left(\mathrm{~d}, 2 \mathrm{H}, \mathrm{PCH}_{2} \mathrm{P},{ }^{2} \mathrm{~J}_{\mathrm{P}-\mathrm{H}}=14.00 \mathrm{~Hz}\right), 4.33(\mathrm{t}, 1 \mathrm{H}, \mathrm{PCH}), 7.27-7.90$ (m, 24H, Ph). ${ }^{31} \mathrm{P}$ NMR $\left(202.45 \mathrm{MHz}, \mathrm{CDCl}_{3}\right) \delta_{\mathrm{P}}(\mathrm{ppm}):-26.48\left(\mathrm{~d}, \mathrm{PPh}_{2},{ }^{2} \mathrm{~J}_{\mathrm{P}-\mathrm{P}}=64.18 \mathrm{~Hz}\right)$, $15.35\left(\mathrm{~d}, \mathrm{PCH},{ }^{2} \mathrm{~J}_{\mathrm{P}-\mathrm{P}}=63.98 \mathrm{~Hz} .{ }^{13} \mathrm{C}\right.$ NMR $\left(62.90 \mathrm{MHz}, \mathrm{CDCl}_{3}\right) \delta_{\mathrm{C}}(\mathrm{ppm}): 183.18(\mathrm{~s}, \mathrm{CO})$, 127.40-144.76 (m, Ph), $45.62(\mathrm{~s}, \mathrm{CH}), 25.35\left(\mathrm{dd}, \mathrm{CH}_{2},{ }^{1} \mathrm{~J}_{\mathrm{P}-\mathrm{C}}=59.03,32.20\right)$.

\subsection{Synthesis of the $\mathbf{P d} / \mathbf{P t}(\mathrm{II})$ complexes}

General procedure: To a dichloromethane solution of $\left[\mathrm{MCl}_{2}(\mathrm{cod})\right](\mathrm{M}=\mathrm{Pd}$ or $\mathrm{Pt})(0.5 \mathrm{mmol}, 5$ $\mathrm{mL})$, a solution of ylide $(0.5 \mathrm{mmol})\left(5 \mathrm{~mL}, \mathrm{CH}_{2} \mathrm{Cl}_{2}\right)$ was added. The resulting solution was stirred for $2 \mathrm{~h}$ at room temperature and then concentrated to a $c a .2 \mathrm{~mL}$ under reduced pressure and treated with n-hexane $(15 \mathrm{~mL})$ to afford the $\mathrm{Pd}(\mathrm{II})$ or $\mathrm{Pt}(\mathrm{II})$ complexes of phosphorus ylide.

2.4.1. Data for $\mathrm{Pd}(\mathrm{II})$ complex $\left[\mathrm{PdCl}_{2}\left(\mathrm{Ph}_{2} \mathrm{PCH}_{2} \mathrm{PPh}_{2} \mathrm{C}(\mathrm{H}) \mathrm{C}(\mathrm{O}) \mathrm{C}_{6} \mathrm{H}_{4}-m-\mathrm{Br}\right)\right]$ (3). Yield: $0.303 \mathrm{~g}(80 \%)$. Anal. Calc. for $\mathrm{C}_{33} \mathrm{H}_{27} \mathrm{BrCl}_{2} \mathrm{OP}_{2} \mathrm{Pd}(\%)$ : C, 52.24; H, 3.59. Found: $\mathrm{C}, 52.18 ; \mathrm{H}$, 3.62. M.p. $198-201{ }^{\circ} \mathrm{C}(\mathrm{dec})$. Selected IR absorption in $\mathrm{KBr}\left(\mathrm{cm}^{-1}\right) v(\mathrm{CO}): 1619 .{ }^{1} \mathrm{H}$ NMR $(89.60$ MHz, DMSO-d $\left.{ }_{6}\right) \delta_{\mathrm{H}}(\mathrm{ppm}): 4.65\left(\mathrm{br}, \mathrm{PCH}_{2} \mathrm{P}, 2 \mathrm{H}\right), 5.98(\mathrm{~s}, 1 \mathrm{H}, \mathrm{PCH}), 7.25-8.31(\mathrm{~m}, 24 \mathrm{H}, \mathrm{Ph})$. ${ }^{31} \mathrm{P}$ NMR (36.26 MHz, DMSO-d 6 ) $\delta_{\mathrm{P}}(\mathrm{ppm}): 26.73\left(\mathrm{~d}, \mathrm{PPh}_{2},{ }^{2} \mathrm{~J}_{\mathrm{P}-\mathrm{P}}=49.07 \mathrm{~Hz}\right), 38.04(\mathrm{~d}, \mathrm{PCH}$, $\left.{ }^{2} \mathrm{~J}_{\mathrm{P}-\mathrm{P}}=47.29 \mathrm{~Hz}\right) .{ }^{13} \mathrm{C}$ NMR $\left(62.90 \mathrm{MHz}, \mathrm{DMSO}-\mathrm{d}_{6}\right) \delta_{\mathrm{C}}(\mathrm{ppm}): 195.80(\mathrm{~s}, \mathrm{CO}), 121.32-140.04$ $(\mathrm{m}, \mathrm{Ph}), 32.62\left(\mathrm{~d}, \mathrm{PCH},{ }^{1} \mathrm{~J}_{\mathrm{P}-\mathrm{C}}=56.48 \mathrm{~Hz}\right)$.

This article is protected by copyright. All rights reserved. 
2.4.2. Data for $\mathrm{Pd}(\mathrm{II})$ complex $\left[\mathrm{PdCl}_{2}\left(\mathrm{Ph}_{2} \mathrm{PCH}_{2} \mathrm{PPh}_{2} \mathrm{C}(\mathrm{H}) \mathrm{C}(\mathrm{O}) \mathrm{C}_{6} \mathrm{H}_{4}-p-\mathrm{CN}\right)\right]$ (4). Yield: 0.248 g (90\%). Anal. Calc. for $\mathrm{C}_{34} \mathrm{H}_{27} \mathrm{NCl}_{2} \mathrm{OP}_{2} \mathrm{Pd}(\%)$ : C, 57.94; H, 3.86; N, 1.99. Found: $\mathrm{C}$, 57.83; H, 3.82; N, 2.08. M.p. $190-192{ }^{\circ} \mathrm{C}$ (dec). Selected IR absorption in $\mathrm{KBr}\left(\mathrm{cm}^{-1}\right) v(\mathrm{CO})$ : 1620. ${ }^{-1} \mathrm{H}$ NMR (250.13 MHz, DMSO-d $\left.{ }_{6}\right) \delta_{\mathrm{H}}(\mathrm{ppm}): 4.86\left(\mathrm{t}, \mathrm{PCH}_{2} \mathrm{P}, 2 \mathrm{H}\right), 6.03$ (s, 1H, PCH), 7.20-8.12 (m, 24H, Ph). ${ }^{31} \mathrm{P}$ NMR (101.24 MHz, DMSO-d $\left.{ }_{6}\right) \delta_{\mathrm{P}}(\mathrm{ppm}): 27.51\left(\mathrm{~b}, \mathrm{PPh}_{2}\right), 37.66(\mathrm{~d}$, $\left.\mathrm{PCH},{ }^{2} \mathrm{~J}_{\mathrm{P}-\mathrm{P}}=42.21 \mathrm{~Hz}\right) .{ }^{13} \mathrm{C}$ NMR $\left(62.90 \mathrm{MHz}, \mathrm{DMSO}-\mathrm{d}_{6}\right) \delta_{\mathrm{C}}(\mathrm{ppm}): 196.12(\mathrm{~s}, \mathrm{CO}), 115.03-$ $141.73(\mathrm{~m}, \mathrm{Ph}), 33.43\left(\mathrm{~d}, \mathrm{PCH},{ }^{1} \mathrm{~J}_{\mathrm{P}-\mathrm{C}}=54.97 \mathrm{~Hz}\right)$.

2.4.3. Data for $\mathrm{Pt}(\mathrm{II})$ complex $\left[\mathrm{PtCl}_{2}\left(\mathrm{Ph}_{2} \mathrm{PCH}_{2} \mathrm{PPh}_{2} \mathrm{C}(\mathrm{H}) \mathrm{C}(\mathrm{O}) \mathrm{C}_{6} \mathrm{H}_{4}-m-\mathrm{Br}\right)\right]$ (5). Yield: 0.305 g (72\%). Anal. Calc. for $\mathrm{C}_{33} \mathrm{H}_{27} \mathrm{BrCl}_{2} \mathrm{OP}_{2} \mathrm{Pt}(\%)$ : C, 46.77; H, 3.21. Found: C, 46.90; H, 3.34. M.p. $231-233{ }^{\circ} \mathrm{C}(\mathrm{dec})$. Selected IR absorption in $\mathrm{KBr}\left(\mathrm{cm}^{-1}\right) v(\mathrm{CO}): 1634 .{ }^{1} \mathrm{H}$ NMR $(250.13$ $\left.\mathrm{MHz}, \mathrm{CDCl}_{3}\right) \delta_{\mathrm{H}}(\mathrm{ppm}): 4.77\left(\mathrm{br}, \mathrm{PCH}_{2} \mathrm{P}, 2 \mathrm{H}\right), 5.56\left(\mathrm{~s}, 1 \mathrm{H}, \mathrm{PCH},{ }^{3} \mathrm{~J}_{\mathrm{Pt}-\mathrm{H}}=65.07 \mathrm{~Hz}\right), 7.05-8.29$ (m, 24H, Ph). ${ }^{31} \mathrm{P}$ NMR (101.24 MHz, CDCl $) \delta_{\mathrm{P}}(\mathrm{ppm}): 3.91\left(\mathrm{~d}, \mathrm{PPh}_{2},{ }^{1} \mathrm{~J}_{\mathrm{Pt}-\mathrm{P}}=3947.73 \mathrm{~Hz},{ }^{2} \mathrm{~J}_{\mathrm{P}-\mathrm{P}}\right.$ $=36.85 \mathrm{~Hz}), 41.14\left(\mathrm{~d}, \mathrm{PCH},{ }^{2} \mathrm{~J}_{\mathrm{P}-\mathrm{P}}=36.97 \mathrm{~Hz}\right) .{ }^{13} \mathrm{C} \mathrm{NMR}\left(62.90 \mathrm{MHz}, \mathrm{CDCl}_{3}\right) \delta_{\mathrm{C}}(\mathrm{ppm}): 194.47$ (s, CO), 119.95-141.72 (m, Ph), $27.73\left(\mathrm{~d}, \mathrm{PCH},{ }^{1} \mathrm{~J}_{\mathrm{P}-\mathrm{C}}=56.37 \mathrm{~Hz}\right)$.

2.4.4. Data for $\mathrm{Pt}(\mathrm{II})$ complex $\left[\mathrm{PtCl}_{2}\left(\mathrm{Ph}_{2} \mathrm{PCH}_{2} \mathrm{PPh}_{2} \mathrm{C}(\mathrm{H}) \mathrm{C}(\mathrm{O}) \mathrm{C}_{6} \mathrm{H}_{4}-p\right.\right.$-CN)] (6). Yield: 0.311 g (79\%). Anal. Calc. for $\mathrm{C}_{34} \mathrm{H}_{27} \mathrm{NCl}_{2} \mathrm{OP}_{2} \mathrm{Pt}(\%)$ : C, 51.46; H, 3.43; N, 1.77. Found: C, 51.59; $\mathrm{H}$, 3.57; N, 1.90. M.p. $218-220{ }^{\circ} \mathrm{C}(\mathrm{dec})$. Selected IR absorption in $\mathrm{KBr}\left(\mathrm{cm}^{-1}\right) v(\mathrm{CO}): 1601 .{ }^{1} \mathrm{H}$ NMR (250.13 MHz, $\left.\mathrm{CDCl}_{3}\right) \delta_{\mathrm{H}}(\mathrm{ppm}): 4.85\left(\mathrm{dd}, \mathrm{PCH}_{2} \mathrm{P}, 2 \mathrm{H}\right), 5.58\left(\mathrm{~s}, 1 \mathrm{H}, \mathrm{PCH},{ }^{3} \mathrm{~J}_{\mathrm{Pt}-\mathrm{H}}=70.04\right.$ $\mathrm{Hz}), 6.98-8.04$ (m, 24H, Ph). ${ }^{31} \mathrm{P}$ NMR $\left(101.24 \mathrm{MHz}, \mathrm{CDCl}_{3}\right) \delta_{\mathrm{P}}(\mathrm{ppm}): 2.00\left(\mathrm{~d}, \mathrm{PPh}_{2},{ }^{1} \mathrm{~J}_{\mathrm{Pt}-\mathrm{P}}=\right.$ $\left.3921.02 \mathrm{~Hz},{ }^{2} \mathrm{~J}_{\mathrm{P}-\mathrm{P}}=38.47 \mathrm{~Hz}\right), 39.62\left(\mathrm{~d}, \mathrm{PCH},{ }^{2} \mathrm{~J}_{\mathrm{P}-\mathrm{P}}=39.48 \mathrm{~Hz}\right) .{ }^{13} \mathrm{C} \mathrm{NMR}\left(62.90 \mathrm{MHz}, \mathrm{CDCl}_{3}\right)$

This article is protected by copyright. All rights reserved. 
$\delta_{\mathrm{C}}(\mathrm{ppm}): 197.17(\mathrm{~s}, \mathrm{CO}), 120.60-136.32(\mathrm{~m}, \mathrm{Ph}), 119.17(\mathrm{~s}, \mathrm{CN}), 31.92\left(\mathrm{~d}, \mathrm{PCH},{ }^{1} \mathrm{~J}_{\mathrm{P}-\mathrm{C}}=53.46\right.$ $\mathrm{Hz})$.

\subsection{Crystallography}

Data collection for complex $\mathbf{3}$ was performed on an Oxford Diffraction SuperNova diffractometer using mirror monochromated Mo K $\alpha$ radiation $(\lambda=0.71073 \AA)$ at $130 \mathrm{~K}$. Using Olex $2^{[36]}$, the structure was solved with the ShelXT ${ }^{[37]}$ structure solution program using Direct Methods and refined with the ShelXL ${ }^{[38]}$ refinement package using Least Squares minimization on $F^{2}$. Gaussian absorption corrections were applied to the data. All non-hydrogen atoms were refined with anisotropic displacement parameters, using all data.

Also, Crystallographic data for complex 4 were collected on an MAR345 dtb diffractometer equipped with image plate detector using Mo Ka X-ray radiation. The structure was solved by direct methods using SHELXS-97, and refined using full-matrix least-squares method on $F^{2}$, SHELXL-97. All non-hydrogen atoms were refined anisotropically. Hydrogen atoms were added at ideal positions and refined using a riding model.

\subsection{Computational studies}

The geometries of the aforementioned Pt(II) complexes were fully optimized at BP86 ${ }^{[39,}$ ${ }^{40]} / \mathrm{def}^{-}-\mathrm{SVP}^{[41]}$ level of theory. It has been shown that BP86 is a suitable level for calculation of bonding situation between the $\mathrm{M} \leftarrow \mathrm{L}$ in such as these complexes. ${ }^{[42-50]}$ All calculations were performed using the Gaussian 09 set of programs. ${ }^{[51]}$ NBO analyses ${ }^{[52]}$ were also carried out with 
the internal model GAUSSIAN 09. For bonding analyses between two fragment (Ylide and $\mathrm{PtCl}_{2}$ ), the terms of energy decomposition analysis (EDA) were carried out at BP86/TZ2P (ZORA)//BP86/def2-TZVPP with C1 symmetry. The basis sets for all elements have triple- $\zeta$ quality augmented by one set of polarization functions (ADF basis set TZ2P (ZORA)) with the program package ADF2009.01.

\subsection{Typical procedure for the Suzuki-Miyaura coupling reaction}

General procedure: A mixture of aryl chloride $(0.5 \mathrm{mmol})$, arylboronic acid $(0.75 \mathrm{mmol})$, palladacycle complex $(0.005 \mathrm{mmol})$ and $\mathrm{K}_{2} \mathrm{CO}_{3}(1 \mathrm{mmol})$ was heated at $110{ }^{\circ} \mathrm{C}$ in $\mathrm{DMF} / \mathrm{H}_{2} \mathrm{O}(2$ $\mathrm{mL}, 1: 1)$ for $6 \mathrm{~h}$ in the presence of air. The reactions were monitored by thin-layer chromatography (TLC). The reaction mixture was then cooled to room temperature. After completion of reaction, the mixture was diluted with $\mathrm{n}$-hexane $(15 \mathrm{~mL})$ and water $(15 \mathrm{~mL})$. The organic layer was washed with brine $(15 \mathrm{~mL})$ and dried over $\mathrm{CaCl}_{2}$. The solvent was evaporated under reduced pressure and a crude product was obtained, which was analyzed by ${ }^{1} \mathrm{H}$ and ${ }^{13} \mathrm{C}$ NMR.

2.7.1. Data for Ph-Ph (7a). M.p. $67-69{ }^{\circ} \mathrm{C} .{ }^{1} \mathrm{H}$ NMR (400.61 MHz, $\left.\mathrm{CDCl}_{3}\right) \delta_{\mathrm{H}}$ (ppm): 7.40$7.64\left(\mathrm{~m}, 10 \mathrm{H}\right.$, phenyl). ${ }^{13} \mathrm{C}$ NMR (100.62 $\left.\mathrm{MHz}, \mathrm{CDCl}_{3}\right) \delta_{\mathrm{C}}(\mathrm{ppm}): 141.29,128.79,127.29$, 127.21.

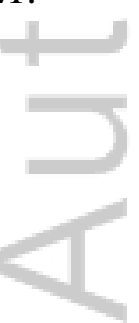


2.7.2. Data for $\boldsymbol{p}$-CHO-Ph-Ph (7b). M.p. $89-91{ }^{\circ} \mathrm{C} .{ }^{1} \mathrm{H}$ NMR $\left(400.61 \mathrm{MHz}, \mathrm{CDCl}_{3}\right) \delta_{\mathrm{H}}(\mathrm{ppm})$ : 7.40-7.86 (m, 9H, phenyl), 9.98 (s, 1H, CHO). ${ }^{13} \mathrm{C}$ NMR (100.62 MHz, $\left.\mathrm{CDCl}_{3}\right) \delta_{\mathrm{C}}(\mathrm{ppm}): 191.94$ (s, CO), 147.23, 139.74, 135.22, 130.29, 129.03, 128.49, 127.71, 127.39 .

2.7.3. Data for $\boldsymbol{p}$ - $\mathrm{CH}_{3}$ O-Ph-Ph (7c). M.p. $90-92{ }^{\circ} \mathrm{C} .{ }^{1} \mathrm{H}$ NMR $\left(400.61 \mathrm{MHz}, \mathrm{CDCl}_{3}\right) \delta_{\mathrm{H}}(\mathrm{ppm})$ : $3.78\left(\mathrm{~s}, 3 \mathrm{H}, \mathrm{OCH}_{3}\right), 6.89-7.49$ (m, 9H, phenyl). ${ }^{13} \mathrm{C} \mathrm{NMR}\left(100.62 \mathrm{MHz}, \mathrm{CDCl}_{3}\right) \delta_{\mathrm{C}}(\mathrm{ppm})$ : $159.15,140.84,133.79,128.73,128.17,127.75,126.75,126.67,114.30,114.20,55.36(\mathrm{~s}$, $\left.\mathrm{OCH}_{3}\right)$.

2.7.4. Data for $\boldsymbol{p}$ - $\mathrm{CH}_{3} \mathrm{OC}-\mathrm{Ph}-\mathrm{Ph}-\mathrm{Et}$ (7d). M.p. $105-108{ }^{\circ} \mathrm{C} .{ }^{1} \mathrm{H}$ NMR $\left(400.61 \mathrm{MHz}, \mathrm{CDCl}_{3}\right)$ $\delta_{\mathrm{H}}(\mathrm{ppm}): 1.24\left(\mathrm{t}, 3 \mathrm{H}, \mathrm{CH}_{3}\right), 2.51\left(\mathrm{~s}, 3 \mathrm{H}, \mathrm{CH}_{3}\right), 2.59\left(\mathrm{q}, 2 \mathrm{H}, \mathrm{CH}_{2}\right), 7.25-8.01\left(\mathrm{~m}, 8 \mathrm{H}\right.$, phenyl). ${ }^{13} \mathrm{C}$ NMR (100.62 MHz, $\left.\mathrm{CDCl}_{3}\right) \delta_{\mathrm{C}}(\mathrm{ppm}): 197.76$ (s, CO), 154.74, 144.57, 137.18, 135.58, 129.3, $128.89,128.49,127.18,126.90,28.55\left(\mathrm{~s}, \mathrm{CH}_{2}\right), 26.64\left(\mathrm{~s}, \mathrm{CH}_{3}\right), 15.52\left(\mathrm{~s}, \mathrm{CH}_{3}\right)$.

2.7.5. Data for $\boldsymbol{p}$ - $\mathbf{C H}_{3}-\mathbf{P h}-\mathbf{P h}(\mathbf{7 e})$. M. p. $51-53{ }^{\circ} \mathrm{C} .{ }^{1} \mathrm{H}$ NMR $\left(89.61 \mathrm{MHz}, \mathrm{CDCl}_{3}\right) \delta_{\mathrm{H}}(\mathrm{ppm})$ : $2.61\left(\mathrm{~S}, 3 \mathrm{H}, \mathrm{CH}_{3}\right), 7.46-8.09$ (m, 9H, phenyl). ${ }^{13} \mathrm{C} \mathrm{NMR}\left(100.62 \mathrm{MHz}, \mathrm{CDCl}_{3}\right) \delta_{\mathrm{C}}(\mathrm{ppm})$ : 137.60, 137.46, 134.67, 129.73, 129.09, 128.76, 127.85, 126.85, 126.77, $21.27\left(\mathrm{~s}, \mathrm{CH}_{3}\right)$.

\section{Results and discussion}

\subsection{Synthesis}

This article is protected by copyright. All rights reserved. 
Reaction of diphosphine $\mathrm{Ph}_{2} \mathrm{PCH}_{2} \mathrm{PPh}_{2}$ with 1 equiv. of 2,3'-dibromoacetophenone or 2bromo-4'-cyanoacetophenone gave the new phosphonium salts $\mathbf{S}_{\mathbf{1}}$ and $\mathbf{S}_{\mathbf{2}}$. Further treatment of these salts with triethyl amine led to elimination of $\mathrm{HBr}$ and formation of new unsymmetrical phosphorus ylides $\mathbf{Y}_{\mathbf{1}}$ and $\mathbf{Y}_{2}$. Reaction of these ligands with $\left[\mathrm{MCl}_{2}(\operatorname{cod})\right](\mathrm{M}=\mathrm{Pd}$ and $\mathrm{Pt})$ in equimolar ratio yielded the new $\mathrm{P}, \mathrm{C}$-chelated pallada- and platinacycle complexes 3-6 (Scheme 1).

\section{Scheme 1 here}

\subsection{Spectroscopy}

The structure of products was characterized successfully by ${ }^{1} \mathrm{H},{ }^{13} \mathrm{C}$ and ${ }^{31} \mathrm{P} \mathrm{NMR}$ spectroscopic methods and other conventional techniques such as IR and elemental analysis. Table 1 shows the brief summary of these data.

\section{Table 1 here}

Also, the exact structure of complexes $\mathbf{3}$ and $\mathbf{4}$ with atomic resolution were being unequivocally determined by single crystal X-ray diffraction technique. The CHN elemental analysis of pallada- and platinacycle complexes indicates a 1:1 stoichiometry between the $\mathrm{MCl}_{2}$ $(\mathrm{M}=\mathrm{Pd}$ and $\mathrm{Pt})$ and phosphorus ylide.

The $v(\mathrm{CO})$ band in the IR spectra of phosphorus ylides $\mathbf{Y}_{\mathbf{1}}$ and $\mathbf{Y}_{\mathbf{2}}$ were observed at lower frequencies compared to the related phosphonium salts $\mathbf{S}_{\mathbf{1}}$ and $\mathbf{S}_{\mathbf{2}}$, indicating formation of $\mathrm{P}=\mathrm{C}$ double bond and decrease of $\mathrm{C}=\mathrm{O}$ bond order. Coordination of ylide through the carbon atom 
(chelating mode) causes an increase in the $v(\mathrm{CO})$ frequency, while for O-coordination a lowering shift for this frequency is expected. ${ }^{[53]}$ The $v(\mathrm{CO})$ in IR spectra of complexes 3-6 occurs around $1600-1630 \mathrm{~cm}^{-1}$ and shows significantly shift to higher frequency than those of related phosphorus ylides. Thus, the obtained IR data indicates that the chelation of ylide to $\mathrm{Pd}(\mathrm{II})$ and $\mathrm{Pt}(\mathrm{II})$ occurs through the ylidic carbon atom and $\mathrm{PPh}_{2}$ group (see supplementary data). ${ }^{[17,20]}$

The ${ }^{31}$ P NMR spectra of phosphonium salts $\mathbf{S}_{\mathbf{1}}$ and $\mathbf{S}_{\mathbf{2}}$ show two doublets around 21, -28 and 24, $-25 \mathrm{ppm}$, which are assigned to the $\mathrm{PCH}$ and $\mathrm{PPh}_{2}$ groups, respectively. In ${ }^{31} \mathrm{P}$ NMR spectra of ylides $\mathbf{Y}_{1}$ and $\mathbf{Y}_{2}$, the phosphonium group of these compounds shows upfield shifts compared to that of parent phosphonium salts. These peaks were shifted to around 14, -26 and 15, $-26 \mathrm{ppm}$, respectively, consistent with some increase of electron density in the $\mathrm{P}=\mathrm{C}$ bonds. The ${ }^{31} \mathrm{P}$ chemical shift values for complexes 3-6 appear to be shifted to downfield with respect to phosphorus ylides $\mathbf{Y}_{\mathbf{1}}$ and $\mathbf{Y}_{\mathbf{2}}$, indicating that coordination of the ylide has been occurred. The ${ }^{31} \mathrm{P}$ NMR spectra of palladacycles 3 and $\mathbf{4}$ exhibit two doublets around 26, 38 and 27, 37 ppm, which are assigned to the $\mathrm{PPh}_{2}$ and $\mathrm{PCH}$ groups, respectively. Whereas, the ${ }^{31} \mathrm{P}$ NMR spectra of platinacycles 5 and $\mathbf{6}$ show these peaks around 41, 4 and 40,2 ppm along with two satellite peaks due to ${ }^{195} \mathrm{Pt}-{ }^{31} \mathrm{P}$ coupling (see supplementary data).

Also, the ${ }^{1} \mathrm{H}$ NMR spectra show all the expected resonances of compounds $\mathbf{S}_{\mathbf{1}}, \mathbf{S}_{\mathbf{2}}, \mathbf{Y}_{\mathbf{1}}, \mathbf{Y}_{\mathbf{2}}$ and 3-6. The ${ }^{1} \mathrm{H}$ NMR spectra of ylides $\mathbf{Y}_{\mathbf{1}}$ and $\mathbf{Y}_{\mathbf{2}}$ show an upfield shift for the $\mathrm{CH}$ signals compared to the those of phosphonium salts $\mathbf{S}_{\mathbf{1}}$ and $\mathbf{S}_{\mathbf{2}}$ indicating that synthesis of the ylides has occurred. The ${ }^{1} \mathrm{H}$ chemical shift values for complexes 3-6 appear to be shifted to downfield with respect to 
the parent ylide, as a consequence of P, C-coordination character of the ylide. Similar behavior was observed earlier in the case of ylide complexes of copper(I) chlorides. ${ }^{[18]}$

In the ${ }^{13} \mathrm{C}$ NMR spectra of ylides $\mathbf{Y}_{1}$ and $\mathbf{Y}_{2}$, a downfield shift of the signals due to the ylidic carbon is also observed and it was attributed to the change in hybridization of the ylidic carbon atom. Further, the signals due to the carbonyl group in ${ }^{13} \mathrm{C}$ NMR spectra of ylides $\mathbf{Y}_{\mathbf{1}}$ and $\mathbf{Y}_{\mathbf{2}}$ shifted to higher field compared to the parent phosphonium salts. The most important aspect of ${ }^{13} \mathrm{C}$ NMR spectra of these complexes is the downfield shift of signals due to the carbonyl group. The ${ }^{13} \mathrm{C}$ NMR spectra of complexes 3-6 show the characteristic peaks of carbonyl group around $196 \mathrm{ppm}$, compare to $183 \mathrm{ppm}$ for the same carbon in the parent free ylides, indicating a much lower shielding of the carbon of the $\mathrm{CO}$ group in these complexes (see supplementary data). Thus, the spectral data indicate the bidentate coordination of the ylides through both the phosphine group and the ylidic carbon atom.

\subsection{Crystallography}

Suitable single crystals of complexes $\mathbf{3}$ and $\mathbf{4}$ were grown by vapor diffusion of methanol into DMSO solution. The molecular structures of $\mathbf{3}$ and $\mathbf{4}$ were shown in Fig. 1 and Fig. 2, respectively. Relevant parameters concerning data collection and refinement were given in Table 2. Selected bond distances and angles for the unit cells of $\mathbf{3}$ and $\mathbf{4}$ are displayed in Table 3.

\section{Fig. 1 here}

Fig. 2 here 


\section{Table 2 here}

\section{Table 3 here}

Hydrogen atoms of complex $\mathbf{3}$ were located in ideal positions. There were two independent molecules in the asymmetric unit. For one of the molecules, the 3-bromophenylethanone group and one of the phenyl rings were found to be disordered and no evidence of disorder was seen in the rest of the molecule. The main difference between them is in the orientation of the 3bromophenylethanone group, with the torsion angle $\mathrm{O} 1$ - C2...C5 - Br1 being $-177.51(19)^{\circ}$, for molecule 1 and the torsion angle $\mathrm{O} 2-\mathrm{C} 35 \ldots \mathrm{C} 38-\mathrm{Br} 2$ being $-22.6(18)^{\circ}$ for molecule 2. The dihedral angles of the keto group with the aromatic rings are $2.79(15)^{\circ}$ and $21.0(5)^{\circ}$, respectively.

For molecule 1 there are three weak intramolecular $\mathrm{C}-\mathrm{H} . . . \mathrm{Cl}$ interactions, between hydrogen atoms on the aromatic rings and the coordinated chloride. All other C-H...X interactions are intermolecular interactions that link the molecules into a 3D network. Refinement was carried out with the atoms of both groups distributed over 2 positions, the geometry of each component being restrained to be equal. The final occupancy factors were $0.8057(17)$ and $0.1943(17)$, for the 3-bromophenylethanone group, and 0.575(19) and 0.425(19).

The coordinates of the two molecules were chosen such that C1 and C34 had both the S configuration. Both Pd atoms are in a tetrahedrally distorted square planar environment, with the $\mathrm{P}-\mathrm{Pd}-\mathrm{Cl}$ and the $\mathrm{C}-\mathrm{Pd}-\mathrm{Cl}$ angles being significantly less than $180^{\circ}$. This distortion is more 
pronounced for molecule 1 than molecule 2. The Pd-containing five-membered rings both adopts a half-chair conformation, with C1 lying above $(0.507(3) \AA)$ and P1 lying below $(-0.368(3) \AA)$ the plane of the other 3 atoms. For molecule 2, C34 lies below (-0.269(3) $\AA$ ) and P1 lies above (0.487(3) $\AA$ ) the plane.

\subsection{Theoretical studies}

In 2014, Samiee and his co-worker confirmed that the structure of $\left.\left[\mathrm{R}_{2} \mathrm{P}\left(\mathrm{CH}_{2}\right)_{\mathrm{n}} \mathrm{PRC}(\mathrm{H}) \mathrm{C}(\mathrm{O}) \mathrm{R}\right) \mathrm{MX}_{2}\right](\mathrm{R}=\mathrm{Me}, \mathrm{Ph} ; \mathrm{M}=\mathrm{Ni}, \mathrm{Pt}$ and $\mathrm{Pd}$ and $\mathrm{X}=\mathrm{Cl}, \mathrm{Br}, \mathrm{I} ; \mathrm{n}=1,2,3)$ complexes are square planar. In these structures, two halogen atoms are oriented in cis

position. ${ }^{[54]}$ Thus according to this reports, we considered the square planar structures for $\left[\mathrm{Y}_{1} \mathrm{PtCl}_{2}\right] \quad$ and $\quad\left[\mathrm{Y}_{2} \mathrm{PtCl}_{2}\right] \quad\left(\mathbf{Y}_{1}=\quad \mathrm{Ph}_{2} \mathrm{PCH}_{2} \mathrm{PPh}_{2} \mathrm{C}(\mathrm{H}) \mathrm{C}(\mathrm{O}) \mathrm{C}_{6} \mathrm{H}_{4}-\mathrm{m}-\mathrm{Br} \quad\right.$ and $\quad \mathbf{Y}_{2}=$ $\left.\mathrm{Ph}_{2} \mathrm{PCH}_{2} \mathrm{PPh}_{2} \mathrm{C}(\mathrm{H}) \mathrm{C}(\mathrm{O}) \mathrm{C}_{6} \mathrm{H}_{4}-\mathrm{p}-\mathrm{CN}\right)$ complexes. A theoretical study on structure and nature of bond in $\left[\mathrm{Y}_{1} \mathrm{PtCl}_{2}\right]$ and $\left[\mathrm{Y}_{2} \mathrm{PtCl}_{2}\right]$ complexes with square planar structures have been reported at the BP86 level using def2-SVP basis set. The optimized structures of $\left[\mathrm{Y}_{1} \mathrm{PtCl}_{2}\right]$ and $\left[\mathrm{Y}_{2} \mathrm{PtCl}_{2}\right]$ complexes at the BP86/def2-SVP level of theory are given in Fig. 3, and important bond lengths and bond angles extracted from optimized geometry are given in Table 4 .

\section{Fig. 3 here}

Table 4 here 
The result show that the optimized' bond lengths and bond angles for $\left[\mathrm{Y}_{1} \mathrm{PtCl}_{2}\right]$ and $\left[\mathrm{Y}_{2} \mathrm{PtCl}_{2}\right]$ are same and these data are in good agreement with those which recently reported with Samiee and his co-worker for $\left[\left(\mathrm{Ph}_{2} \mathrm{P}\left(\mathrm{CH}_{2}\right)_{2} \mathrm{PPh}_{2} \mathrm{CHC}(\mathrm{O}) \mathrm{CH}_{3}\right) \mathrm{PtCl}_{2}\right]$ complexes (see Table 4). ${ }^{[54]}$

For studying the nature of metal-ligand bond and/or possible interactions in $\left[\mathrm{Y}_{1} \mathrm{PtCl}_{2}\right]$ and $\left[\mathrm{Y}_{2} \mathrm{PtCl}_{2}\right]$ complexes, the NBO analysis was performed. ${ }^{[51]}$ The values of the Wiberg (WBI) and partial charges on $\mathrm{Pt}, \mathrm{C}$ and $\mathrm{Cl}$ atoms involved in the bonding interactions between $\mathrm{PtCl}_{2}$ and $\mathrm{Y}_{1}$ and $\mathrm{Y}_{2}$ fragments in $\left[\mathrm{Y}_{1} \mathrm{PtCl}_{2}\right]$ and $\left[\mathrm{Y}_{2} \mathrm{PtCl}_{2}\right]$ complexes as well as total charge of $\mathrm{Y}_{1}$ and $\mathrm{Y}_{2}$ fragments were also evaluated through natural population analysis and are given in Table 5.

\section{Table 5 here}

The result showed that the calculated partial charge (q) on both the Pt and $\mathrm{C}$ atoms in the $\mathrm{Pt}-\mathrm{C}$ bonds is negative. Also, the negative value of $\mathrm{q}(\mathrm{C})$ is greater than that for $\mathrm{q}(\mathrm{Pt}$ ) (see Table 5). On the other hand, the negative values of the total charge of $\left[\mathrm{PtCl}_{2}\right]$ fragments show the charge transfer about 0.85 occurred from $\mathrm{Y}_{1}$ and $\mathrm{Y}_{2}$ ligands to $\left[\mathrm{PtCl}_{2}\right]$ fragments in the

complexes. A second-order perturbation theory analysis of the Fock matrix was carried out to evaluate the donor-acceptor interactions on the base of NBO analysis. The values of donoracceptor interactions in $\left[\mathrm{Y}_{1} \mathrm{PtCl}_{2}\right]$ and $\left[\mathrm{Y}_{2} \mathrm{PtCl}_{2}\right]$ complexes are given in Tables 6.

\section{Table 6 here}

The results showed that in the aforementioned complexes, the important donor-acceptor interactions in the case of $\mathrm{Pt}-\mathrm{C}$ bond were carried out from the $\sigma(\mathrm{Pt}-\mathrm{C})$ and $\sigma(\mathrm{Pt}-\mathrm{P})$ as donors to $\sigma^{*}(\mathrm{Pt}-\mathrm{P})$ and $\sigma^{*}(\mathrm{Pt}-\mathrm{C})$ as acceptors (See Table 6). 
for better analysis of the nature of the $\mathrm{Pt}-\mathrm{C}$ bonding between the $\mathrm{Y}_{1}$ and $\mathrm{Y}_{2}$ and $\left[\mathrm{PtCl}_{2}\right]$ fragments in $\left[\mathrm{Y}_{1} \mathrm{PtCl}_{2}\right]$ and $\left[\mathrm{Y}_{2} \mathrm{PtCl}_{2}\right]$ complexes, the quantum chemical calculations in the terms of energy-decomposition analysis at the BP86-D3/TZ2P(ZORA)//BP86/def2-SVP with $\mathrm{C}_{1}$ symmetry by using the program package ADF2009.01 were carried out. The results of the EDA analyses for aforementioned complexes are given in Table 7.

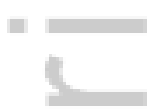

\section{Table 7 here}

As can be seen, the $\Delta E_{\text {int }}$ between two interacted fragments in both $\left[\mathrm{Y}_{1} \mathrm{PtCl}_{2}\right]$ and $\left[\mathrm{Y}_{2} \mathrm{PtCl}_{2}\right]$ complexes are 156.81 and $153.80 \mathrm{kcal} \mathrm{mol}^{-1}$ respectively (See Table 7). The breakdown of the $\Delta \mathrm{E}_{\text {int }}$ values into the Pauli repulsion $\left(\Delta \mathrm{E}_{\text {Pauli }}\right)$ and the three attractive components $\left(\Delta \mathrm{E}_{\text {elstat }}, \Delta \mathrm{E}_{\text {or }}\right.$ and $\left.\Delta \mathrm{E}_{\mathrm{dis}}\right)$ show that roughly $58 \%$ of total interaction comes from the electrostatic attraction $\left(\Delta \mathrm{E}_{\text {elstat }}\right)$ while $\sim 37 \%$ comes from the orbital term $\left(\Delta \mathrm{E}_{\text {orb }}\right)$ and the remaining $(4.7 \%)$ concern to $\Delta \mathrm{E}_{\text {dispersion. }}$ Thus the values of $\Delta E_{\text {elstat }}$ showed that the nature of $\mathrm{Pd}-\mathrm{C}$ bonding in both $\left[\mathrm{Y}_{1} \mathrm{PtCl}_{2}\right]$ and $\left[\mathrm{Y}_{2} \mathrm{PtCl}_{2}\right]$ complexes are more electrostatic. These data are in good agreement with the results of $\mathrm{NBO}$ analysis which shows charge transfer of about 0.85 from $\mathrm{Y}_{1}$ and $\mathrm{Y}_{2}$ to $\left[\mathrm{PtCl}_{2}\right]$ fragment (see Table 6) and the WBI value of 0.49 for $\mathrm{Pt}-\mathrm{C}$ bonds in the complexes.

The covalent bonding between the $\left[\mathrm{PtCl}_{2}\right]$ fragment and $\mathrm{Y}_{1}$ and $\mathrm{Y}_{2}$ Ligands in $\left[\mathrm{Y}_{1} \mathrm{PtCl}_{2}\right]$ and $\left[\mathrm{Y}_{2} \mathrm{PtCl}_{2}\right]$ complexes becomes visible by the calculated deformation densities $\Delta \rho$. Fig. 4 shows the important deformation densities $\Delta \rho$ and the associated energy values which provide about 90 $\%$ of the overall orbital interactions for the complex. As it is illustrated in Fig. 4a and 4b, the dominant terms of $\Delta \mathrm{E}_{\text {orb }}$ for $\left[\mathrm{Y}_{1} \mathrm{PtCl}_{2}\right]$ and $\left[\mathrm{Y}_{2} \mathrm{PtCl}_{2}\right]$ complexes arise from $\Delta \rho 1$ and $\Delta \rho 2$, 
showing $\sigma$ donation from $\mathrm{C}\left(\right.$ ylide) and $\mathrm{P}$ atoms of $\mathrm{Y}_{1}$ and $\mathrm{Y}_{2}$ fragments to $\left[\mathrm{PtCl}_{2}\right]$ in $\left[\mathrm{Y}_{1} \mathrm{PtCl}_{2}\right]$ and $\left[\mathrm{Y}_{2} \mathrm{PtCl}_{2}\right]$ complexes.

Also Fig. 4c, d, e, and f display the deformation density $\Delta \rho 3, \Delta \rho 4, \Delta \rho 5$ and $\Delta \rho 6$ which show the $\pi$-back donation from the $\left[\mathrm{PtCl}_{2}\right]$ fragment to $\mathrm{Y}_{1}$ and $\mathrm{Y}_{2}$ ligand in latter complexes. In the above theoretical studies, the effect of $\mathrm{R}$ group $(\mathrm{R}=\mathrm{Br}$ or $\mathrm{CN})$ substituted on aromatic part of ylides $\left(\mathrm{Y}_{1}\right.$ and $\left.\mathrm{Y}_{2}\right)$ in $\left[\mathrm{Y}_{1} \mathrm{PtCl}_{2}\right]$ and $\left[\mathrm{Y}_{2} \mathrm{PtCl}_{2}\right]$ complexes is negligible.

\section{Fig. 4 here}

\section{Rest of Fig. 4 here}

\subsection{Cyclic voltammetry}

The electrochemical behaviors of the free ylides, $\mathbf{Y}_{\mathbf{1}}$ and $\mathbf{Y}_{\mathbf{2}}$, and their related $\mathrm{Pd}(\mathrm{II})$ and $\mathrm{Pt}(\mathrm{II})$ complexes, 3-6, were studied by cyclic voltammetry. CV curves of the all compounds at a 50 $\mathrm{mVs}^{-1}$ scan rate in acetonitrile solutions $(1 \mathrm{mM})$ are given in Fig. 5. The reduction of $\mathrm{Pd}(\mathrm{II}) / \mathrm{Pd}(0)$ was observed for the $\mathrm{Pd}(\mathrm{II})$ complexes and the reduction of $\mathrm{Pt}(\mathrm{II}) / \mathrm{Pt}(0)$ for the $\mathrm{Pt}(\mathrm{II})$ complexes.

\section{Fig. 5 here}

Fig. 5 shows two cathodic peaks for the ylides $\mathbf{Y}_{\mathbf{1}}$ and $\mathbf{Y}_{2}, \mathrm{C}_{1}$ and $\mathrm{C}_{2}$, at -1.00 and $-0.98 \mathrm{~V}$ versus $\mathrm{Ag} / \mathrm{AgCl}$, respectively. Under the same conditions, the cyclic voltammogram of a $1 \mathrm{mM}$ solution of the complexes, showed irreversible electron transfer. At a scan rate of $50 \mathrm{mVs}^{-1}$, there were two cathodic peaks for $\mathbf{3}, \mathrm{C}_{3}$ and $\mathrm{C}_{\mathrm{Y} 3}$, at -0.91 and $-0.58 \mathrm{~V}$ and one cathodic peak for $\mathbf{5}$, 
$\mathrm{C}_{5}$, at $-0.89 \mathrm{~V}$ corresponding to the redox pair $\mathrm{Pd}(\mathrm{II}) / \mathrm{Pd}(0)$, the reduction of ylide $\mathbf{Y}_{\mathbf{1}}$ and the redox pair $\mathrm{Pt}(\mathrm{II}) / \mathrm{Pt}(0)$, respectively (Fig. 5, curves a and b). This behavior is similar to that reported previously by Champness et al. ${ }^{[5]}$, Batchelor et al ${ }^{[56]}$ and Kvam et al. ${ }^{[57]}$ voltammetric studies of various types of $\mathrm{Pd}(\mathrm{II})$ and $\mathrm{Pt}(\mathrm{II})$ complexes in aprotic solvents.

The cyclic voltammogram of 6 shows one irreversible reduction peak, $\mathrm{C}_{6}$, at $-0.72 \mathrm{~V}$ corresponding to the redox pair $\mathrm{Pt}(\mathrm{II}) / \mathrm{Pt}(0)$ (Fig. 5, curve c). $\mathrm{Pt}(\mathrm{I})$ and $\mathrm{Pt}(\mathrm{III})$ complexes are noted for instability and any reduction or oxidation processes centralized on metal orbitals of $\mathrm{Pt}(\mathrm{II})$ complexes typically exhibit irreversible behavior. ${ }^{[57,58]}$ In $\mathbf{4}$, such as $\mathbf{3}$, peak $\mathrm{C}_{4}(-0.77 \mathrm{~V})$ is assigned to the two electron reduction of $\mathrm{Pd}(\mathrm{II})$ center in the complex and the second reduction peak, $\mathrm{C}_{\mathrm{Y} 2}(-0.49 \mathrm{~V})$, is related to the reduction of ylide $\mathbf{Y}_{\mathbf{2}}$ (Fig. 5, curve d) ${ }^{[17,59]}$ The overall two-electron reduction of the $\mathrm{Pd}(\mathrm{II})$ complexes is expected to take place in separate one-electron steps ${ }^{[55,56,60]}$ and this might be achieved via manipulation of the thermodynamics or electrode kinetics of either step by correct choice of the experimental conditions. Under our experimental conditions, the $\mathrm{Pd}(\mathrm{I})$ complexes are unstable. Thus peaks $\mathrm{C}_{3}$ and $\mathrm{C}_{4}$ in Fig. 5 corresponds to a two-electron reduction of the $\mathrm{Pd}(\mathrm{II})$ complex which is a consequence of the thermodynamic instability of the intermediate one-electron product under our experimental conditions. A comparison of curves a and b with curves $c$ and $d$ in Fig. 5 clearly confirms the presence of $\operatorname{Pd}(\mathrm{II})$ and $\mathrm{Pt}(\mathrm{II})$ centers in the complexes with different chemical environments.

\subsection{Suzuki-Miyaura coupling reaction of aryl chlorides}


The catalytic activity of palladacycles $\mathbf{3}$ and $\mathbf{4}$ in Suzuki-Miyaura coupling reaction was then examined. Initially, we carried out a model reaction to optimize the reaction conditions including base, solvent, temperature and catalyst loading (Table 8). Reaction of phenylboronic acid with chlorobenzene in $\mathrm{DMF} / \mathrm{H}_{2} \mathrm{O}(1: 1)$ at $110^{\circ} \mathrm{C}$ in the presence of $\mathrm{K}_{3} \mathrm{PO}_{4}(1 \mathrm{mmol})$ and $0.05 \mathrm{mmol}$ of catalyst 3 was chosen as model reaction. The reaction led to formation of coupled product in $70 \%$ yield (Table 8, entry 1). Then, a series of experiments was performed to find optimum conditions.

\section{Table 8 here}

At the first stage of optimization, we study the effect of base and solvent on the reaction. Since the solubility and basicity of base strongly depend on the solvent used, these two parameters are closely connected. This optimization was done with commonly used bases and solvents, including organic and inorganic bases and aqueous protic and aprotic solvents. Coupling reactions carried out in presence of $\mathrm{K}_{2} \mathrm{CO}_{3}$ and $\mathrm{K}_{3} \mathrm{PO}_{4}$ give the desired coupling product in moderate to high yields (Table 8 , entries 2,5 and 1,4). However, the reactions in presence of $\mathrm{NEt}_{3}$ did not proceed efficiently even after prolonged stirring at reflux temperature of solvents (Table 8, entries 6 and 9). Among the tested aqueous solvents, $\mathrm{DMF} / \mathrm{H}_{2} \mathrm{O}$ gave higher yields of coupleld product. Also, the reactions in water and non-aqueous DMF led to lower yields, indicating the important role of solubility of base in such catalytic systems (Table 8, entries 10 and 11). 
Next, we investigate the effect of catalyst loading on the reaction. As expected, varying the catalyst loading has a significant effect on the performance of the catalyst. When the loading of palladacycle 3 decreased to $0.005 \mathrm{mmol}$, the coupling reaction gave slightly lower yield of product and the reaction resulted in negligible yield of coupled product when the catalyst loading decreased to $0.0005 \mathrm{mmol}$ (Table 8, entries 12 and 13). A control experiment showed that the reaction fails in blank run (in the absence of Pd-catalyst) and the coupling reaction did not occur during $6 \mathrm{~h}$ (Table 8, entry 14). Also, excessive amount of catalyst increased the yield significantly (Table 8 , entry 15). However, with respect to the economic aspect, $0.005 \mathrm{mmol}$ of catalyst was chosen as the best catalyst loading.

Finally, the reactions were carried out at different temperatures. Decreasing the temperature of reactions has led to the fall of the yields and increasing the reaction time to completion of reactions (Table 8, entries 16 and 17). Thus, the optimum condition obtained for Suzuki-Miyaura coupling reaction consisting the $\mathrm{DMF} / \mathrm{H}_{2} \mathrm{O}$ as solvent, $\mathrm{K}_{2} \mathrm{CO}_{3}$ as base, $0.005 \mathrm{mmol}$ of palladacycle 3 as catalyst and reaction at $110^{\circ} \mathrm{C}$ for $6 \mathrm{~h}$.

Using the optimized reaction conditions, palladacycles $\mathbf{3}$ and $\mathbf{4}$ were applied in reaction of various functionalized aryl chlorides bearing both electron-donating to electron-withdrawing groups with phenylboronic acid. Aryl chlorides were converted into the corresponding coupled products in high yields (Table 9). Conversely, increasing electron density on the aryl chlorides lowered the catalyst activity. That is, excellent yields are achieved when phenylboronic acid reacted with aryl chlorides bearing electron-withdrawing substituent - $\mathrm{CHO}$ and $-\mathrm{COCH}_{3}(\mathrm{Table}$ 
9, entries 1 and 2). Deactivated aryl chlorides 4-chlorotoluene and 4-chloroanisol gave lower yields indicating that the reaction was sensitive to the electron density on the aryl chlorides (Table 9, entries 4 and 5). The reaction of electronically neutral chlorobenzene with phenylboronic acid also produced good amounts of the product (Table 9, entry 3). As can be seen in Table 9, we observed that in all cross-coupling reactions catalyst $\mathbf{3}$ and $\mathbf{4}$ had approximately same catalytic activities. It seems that palladacycles $\mathbf{3}$ and $\mathbf{4}$ produce similar catalytically active species in reactions, since the $m$ - $\mathrm{Br}$ or $p$-CN substituents on the end of the aryl group in phosphorus ylide moiety could not affect significantly the release of catalitically active species.

\section{Table 9 here}

To extend the scope of our work, we next investigated the coupling reaction of aryl chloride substrates with ethyl substituted phenylboronic acid. As expected, electron-donating substituent on arylboronic acid has decreasing effect on the yield of reaction (Table 9, entries 6-10). However, coupling reaction of activated aryl chlorides such as 4-chloroacetophenone gave the coupled boronic acid derivatives in higher yields (Table 9, entry 10).

To evaluate the homogeneous or heterogeneous nature of the active species, we carried out the mercury drop test. ${ }^{[61]}$ Since mercury leads to amalgamation of the surface of a heterogeneous catalyst, and in contrast, $\operatorname{Hg}(0)$ is not expected to have a poisoning effect on homogeneous palladium complexes, the results of desired test help us to determine the nature of the active species. ${ }^{[62]}$ Addition of a drop of mercury to the reaction mixture at $t=0$ did not affect 
the conversion of the reaction, which suggests that amalgamation had not occurred and the catalysis was homogeneous in nature.

As can be seen in Table 9, by using aryl chlorides good amounts of functionalized biaryl derivatives are yielded. The higher $\mathrm{C}-\mathrm{Cl}$ bond dissociation energy compared with $\mathrm{C}-\mathrm{Br}$ and $\mathrm{C}-\mathrm{I}$ bonds disfavors oxidative addition step in catalytic coupling reactions. ${ }^{[63]}$ However, the ideal substrates for coupling reactions are aryl chlorides, since they are cheaper and more widely available than their bromide or iodide analogous. Table 10 shows a comparison between the efficiency of this catalytic system in Suzuki-Miyaura coupling reaction of aryl chlorides and other catalytic systems. The results showed that the most active palladacycles, N-heterocyclic carbenes (NHCs) and pyridine-enhanced precatalyst preparation stabilization and initiation (PEPPSI)-type Pd complexes need to be used in high loadings and showed lower activity with aryl chloride substrates. ${ }^{[64-72]}$ From an industrial view point, the low catalyst loading and short reaction time make this palladacycle as an ideal catalyst for the Suzuki-Miyaura coupling reaction.

\section{Table 10 here}

\section{Conclusions}

In summary, we report the synthesis and characterization of new phosphinium salts $\mathbf{S}_{\mathbf{1}}$ and $\mathbf{S}_{\mathbf{2}}$, phosphorus ylides $\mathbf{Y}_{\mathbf{1}}$ and $\mathbf{Y}_{\mathbf{2}}$, and pallada- and platinacycle 3-6. The palladacycles $\mathbf{3}$ and $\mathbf{4}$ were characterized fully by spectroscopic methods as well as X-ray crystallography method. Results 
showed that chelation of ylide through the ylidic carbon atom and phosphine group afforded a five-membered ring. Also, the catalytic activity of palladacycles $\mathbf{3}$ and $\mathbf{4}$ towards SuzukiMiyaura coupling reaction was investigated. Results showed that the coupling reaction of various aryl chlorides with arylboronic was performed in high yields. The bonding situations between two interacted fragments $\left[\mathrm{MCl}_{2}\right]$ and $\mathbf{Y}_{\mathbf{1}}$ and $\mathbf{Y}_{2}$ ligands in platinacycles $\mathbf{5}$ and $\mathbf{6}$ were investigated based on DFT method by using NBO, EDA, and ETS-NOCV analysis. The NBO shows the charge transfer about $0.85 \mathrm{e}$ from $\mathbf{Y}_{\mathbf{1}}$ and $\mathbf{Y}_{\mathbf{2}}$ ligands to $\left[\mathrm{PtCl}_{2}\right]$ fragment in the complexes. The EDA analysis confirms that the nature of bonds between two interacted fragments in latter complexes is mostly electrostatic, and its contribution in total interaction energy is about $58 \%$. The ETS-NOCV analyses confirm that the mainly contribution to $\Delta \mathrm{E}_{\text {orb }}$ in $\left[\mathrm{Y}_{1} \mathrm{PtCl}_{2}\right]$ and $\left[\mathrm{Y}_{2} \mathrm{PtCl}_{2}\right]$ complexes arise from $\sigma$-donation and shortly from $\pi$ back donation.

\section{Acknowledgements}

Funding of our research from the Bu-Ali Sina University is gratefully acknowledged.

\section{Supplementary material}

Physical measurements and selected ${ }^{31} \mathrm{P},{ }^{13} \mathrm{C}$ and ${ }^{1} \mathrm{H}$ NMR spectra of some compounds can be found in the online version. CCDC 1431938 and 1418881 contains the supplementary crystallographic data for the complexes $\mathbf{3}$ and $\mathbf{4}$, respectively. These data can be obtained free of charge via www.ccdc.cam.ac.uk/data_request/cif or from the Cambridge Crystallographic Data 
Center, 12, Union Road, Cambridge CB2 1EZ, UK. Tel.: +44 01223 762911; or deposit@ccdc.cam.ac.uk.

\section{References}

[1] G. Wittig, Angew. Chem.1980, 92, 671.

[2] A.W. Johnson, Ylides and Imines of Phosphorus; John Wiley and Sons Ltd, Chichester, 1993.

[3] D. Janardanan, R.B. Sunoj, Chem. Eur. J. 2007, 13, 4805.

[4] D. Saravanabharathi, T.S. Venkatakrishnan, M. Nethaji, S.S. Krishnamurthy, Proc. Ind. Acad. Sci. (Chem. Sci.), 2003, 115. 741.

[5] J. Vicente, M.T. Chicote, J.A. Cayuelas, J. Fernandez-Baeza, P.G. Jones, G.M. Sheldrick, P. Espinet,J. Chem. Soc., Dalton Trans.1985, 6, 1163.

[6] E.C. Spencer, M. B. Mariyatra, J.A.K. Howard, A.M. Kenwrigh, K.J. Panchanatheswaran, Organomet. Chem. 2007, 5, 1081.

[7] B. Kalyanasundar, K. Panchanatheswaran, V. Parthasarathi, W. T. Robinson, Bull. Chem. Soc. Jpn. 1999, 72, 33.

[8] S.J. Sabounchei, M. Ahmadi, F. AkhlaghiBagherjeri, H.R. Khavasi, J. Chem. Sci. 2013, 3, 653.

This article is protected by copyright. All rights reserved. 
[9] L.R. Falvello, S. Fernández, R. Navarro, I. Pascual, E.P. Urriolabeitia, J. Chem. Soc., Dalton Trans. 1997,5 763.

[10] D. Aguilar, M.A. Aragüés, R, Bielsa, E, Serrano, T, Soler, L.R. Navarro, E.P. Urriolabeitia, J. Organomet. Chem. 2008, 3, 417.

[11] A. Spannenberg, W. Baumann, U. Rosenthal, Organometallics, 2000, 19, 3991.

[12] S.J. Sabounchei, S. Samiee, S. Salehzadeh, M. Bayat, Z.B. Nojini, D. Morales-Morales, Inorg.Chim.Acta. 2010, 6, 1254.

[13] S.J. Sabounchei, M, Pourshahbaz, R. Karamian, M. Asadbegy, J. Chem. Res.2014, 38, 192

[14] S.J. Sabounchei, M. Pourshahbaz, S. Salehzadeh, M. Bayat, R. Karamian, M, Asadbegy, H.R. Khavasi, Polyhedron.2015, 85, 652.

[15] J. Buckle, P.G. Harrison, T.J. King, J.A. Richards, J. Chem. Soc., Chem. Commun. 1972, $19,1104$.

[16] J.A. Albanese, D.A. Staley, A.L. Rheingold, J.L. Burmeister, Inorg. Chem.1990,29, 2209.

[17] S.J. Sabounchei, S. Samiee, D. Nematollahi, A. Naghipour, D. Morales-Morales, Inorg.Chim.Acta. 2010, 14, 3973.

[18] S.J. Sabounchei, M. Pourshahbaz, A. Hashemi, M. Ahmadi, R. Karamian, M. Asadbegy, H.R. Khavasi, J. Organomet. Chem. 2014, 761, 111. 
[19] D. Soulivong, C. Wieser, M. Marcellin, D. Matt, A. Harriman, L. Toupet, J. Chem. Soc., Dalton Trans. 1997, 13, 2257.

[20] M.M. Ebrahim, H. Stoeckli-Evans, K. Panchanatheswaran, Polyhedron,2007, 14, 3491.

[21] S.J. Sabounchei, M. Panahimehr, M. Ahmadi, Z. Nasri, H. R. Khavasi, J. Organomet. Chem.2013,723 207.

[22] S.J. Sabounchei, M. Panahimehr, M. Ahmadi, F. Akhlaghia, C. Boscovic,C. R. Chim.2014, 17,81 .

[23] S.J. Sabounchei, M. Ahmadi, Z. Nasri, E. Shams, S. Salehzadeh, Y. Gholiee, R. Karamian, M. Asadbegy, S. Samiee, C. R. Chim. 2013, 16, 159.

[24] B.L. Shaw, S.D. Perera, Chem. Commun., 1998, 17,1863.

[25] L.D. Deborah, D.K.B. Maarten, P.F. Gino, G.V. Johannes, W.N.M. Piet, C.J.K. Paul, Eur. J. Inorg. Chem. 2012, 10, 1660.

[26] A. Ghorbani-Choghamarani, A. Naghipour, H. Babaee, B. Notash, Polyhedron., 2016, 10, 1016.

[27] S.J. Sabounchei, M Ahmadi, Catal. Commun. 2013, 37, 114.

[28] S.J. Sabounchei, M. Ahmadi, T. Azizi, M. Panahimehr, Synlett.2014, 25, 336.

[29] S.J. Sabounchei, M Ahmadi,Inorg. Chim.Acta. 2013, 405, 15.

This article is protected by copyright. All rights reserved. 
[30] S.J. Sabounchei, M. Ahmadi, M Panahimehr, F. AkhlaghiBagherjeri, Z. Nasri, J. Mol. Catal. A: Chem. 2014, 383, 249.

[31] S.J. Sabounchei, M. Hosseinzadeh, J. Chem. Sci. 2015, 127, 1919.

[32] R.S. Martin, B. Inés, M.J. Moure, M.T. Herrero, E. Domínguez, Helv. Chim. Acta. 2012, 95,955 .

[33] S.D. Dindulkar, D. Jeong, H. Kim, S. Jung, Carbohydr. Res. 2016, 430, 85.

[34] M. Waheed, N. Ahmed, Tetrahedron Lett. 2016, 57, 3785.

[35] D. Drew, J. R. Doyle, A.G. Shaver, Inorg. Synth.1972, 13,47.

[36] O.V. Dolomanov, L. J. Bourhis, R. J. Gildea, J. A. K. Howard, H. Puschmann, J. Appl. Cryst. 2009, 42, 339.

[37] G.M. Sheldrick, ActaCryst. A. 2015, 71, 3.

[38] G.M. Sheldrick, ActaCryst.A. 2008, 64, 112.

[39] A.D.Becke, Phys. Rev. A. 1988, 38,3098.

[40] J.P. Perdew, Phys. Rev. B. 1986, 33,8822.

[41] A. Schäfer, C. Huber, R. Ahlrichs, J. Chem. Phys. 1994, 100, 5829.

[42] S.J. Sabounchei, M. Sarlakifa, S. Salehzadeh, M. Bayat, M. Pourshahbaz, H.R. Khavasi, Polyhedron. 2012, 38, 131. 
[43] S.J. Sabounchei, M. Pourshahbaz, S. Salehzadeh, M. Bayat, R. Karamia, M. Asadbegy, H.R. Khavasi, Polyhedron. 2015, 85, 652.

[44] S.J. Sabounchei, H. Nemattalab, S. Salehzadeh, S Khani, M. Bayat, H.R. Khavasi, Polyhedron.2008, 27, 2015.

[45] M. Bayat, M. von Hopffgarten, S. Salehzadeh, G. Frenking, J. Organomet. Chem. 2011, 696, 2976.

[46] M. Bayat, S. Salehzadeh, G. Frenking, J. Organomet.Chem. 2012, 697, 74.

[47] M. Bayat, N. Ahmadian, Polyhedron. 2015, 96, 95.

[48] M. Bayat, N. Ahmadian, J. Iranian Chem. Soc. 2016, 13,397.

[49] S.J. Sabounchei, M. Ahmadianpoor, A. Yousefi, A. Hashemi, M. Bayat, A. Sedghi, F. AkhlaghiBagherjeri R. W. Gable, RSC Adv. 2016,6, 28308.

[50] S.J. Sabounchei, A. Yousefi, M. Ahmadianpoor, A. Hashemi, M. Bayat, A. Sedghi, F.A. Bagherjeri, R.W. Gable, Polyhedron. 2016, 117, 273.

[51] M.J. Frisch, G. W. Trucks, H.B. Schlegel, G.E. Scuseria, M.A. Robb, J.R. Cheeseman, G. Scalman, V. Barone, B. Mennucci, G.A. Petersson, H. Nakatsuji, M. Caricato, X. Li, H.P. Hratchian, A.F. Izmaylov, J. Bloino, G. Zheng, J.L. Sonnenberg, M. Hada, M. Ehara, K. Toyota, R. Fukuda, J. Hasegawa, M. Ishida, T. Nakajima, Y. Honda, O. Kitao, H. Nakai, T. Vreven, J.A. Montgomery Jr., J.E. Peralta, F. Ogliaro, M. Bearpark, J.J. Heyd, E. Brothers, K.N. Kudin, V.N. 
Staroverov, R. Kobayashi, J. Normand, K. Raghavachari, A. Rendell, J.C. Burant, S.S. Iyengar,

J. Tomasi, M. Cossi, N. Rega, J.M. Millam, M. Klene, J.E. Knox, J.B. Cross, V. Bakken, C. Adamo, J. Jaramillo, R. Gomperts, R.E. Stratmann, O. Yazyev, A.J. Austin, R. Cammi, C. Pomelli, J.w. Ochterski, R.L. Martin, K. Morokuma, V.G. Zakrzewski, G.A. Voth, P. Salvador, J.J. Dannenberg, S. Dapprich, A.D. Daniels, Ö. Farkas, J.B. Foresman, J.V. Ortiz, J. Cioslowski, D.J. Fox, Gaussian 09, Revision A.02, Gaussian, Inc., Wallingford, CT, 2009.

[52] E. D. Gladdening, A. E. Reed, J. A. Carpenter, F. Weinhold, NBO Version 3.1.

[53] M. Kalyanasundari, K. Panchanatheswaran, W.T. Robinson, H. Wen, J. Organomet. Chem.1995,491, 103.

[54] S.Samiee, Z.Mahdavifar, Polyhedron. 2014, 72.

[55] N.R. Champness, P.F. Kelly, W. Levason, G. Reid, A.M. Slawin, D.J. Williams, Inorg. Chem. 1995, 34, 651.

[56] R.J. Batchelor, F.W. Einstein, I.D. Gay, J. Gu, B.M. Pinto, X. Zhou, Inorg. Chem.1996, 35, 3667.

[57] P.I. Kvam, M. Puzyk, K.P. Balashev, J. Songstad, ActaChim. Scand. 1995, 49, 335.

[58] D.M. Jenkins, J.F. Senn, S. Bernhard, Dalton Trans. 2012, 41, 8077.

[59] S.J. Sabounchei, M. Hosseinzadeh, M. Panahimehr, D. Nematollahi, H.R. Khavasi, S. Khazalpour, Transit. Metal Chem., 2015, 40, 657. 
[60] A.J. Downard, A.M. Bond, A.J. Clayton, L.R. Hanton, D.A.McMorran, Inorg. Chem. 1996, 35,7684 .

[61] G.M. Whitesides, M. Hackett, R.L. Brainard, J.P.P.M.Lavallaye, A.F. Sowinski, A.N.Izumi, S.S. Moore, D.W. Brown, E.M. Staudt, Organometallics. 1985,4, 1819.

[62] A.R. Hajipour, F. Rafiee, Appl. Organomet. Chem. 2012, 26, 51.

[63] Y. Garcia, F. Schoenebeck, C.Y. Legault, C.A. Merlic, K.N. Houk, J. Am. Chem. Soc. 2009, 13, 6632.

[64] T.M. Shaikh, F-E. Hong, Beilstein J. Org. Chem. 2013, 9, 1578.

[65] J. Silberg, T. Schareina, R. Kempe, K. Wurst, M.R. Buchmeiser, J. Organomet. Chem. $2001,622,6$.

[66] A. Ataei, S. Nadri, E. Rafiee, S. Jamali, M. Joshaghani, J. Mol. Catal. A: Chem. 2013, 366, 30.

[67] S.M. Islam, P. Mondal, K. Tuhina, A.S. Roy, S. Mondal, D. Hossain, J. Inorg. Organomet. Polym. 2010, 20, 264.

[68] H. Baier, A. Kelling, H.-J. Holdt, Eur. J. Inorg. Chem. 2015, 11, 1950.

[69] E. Steeples, A. Kelling, U. Schilde, D. Esposito, New J. Chem. 2016, 40, 4922.

[70] S. Yasar, C. Sahin, M. Arslan, I. Ozdemir, J. Organomet. Chem. 2015, 776, 107. 
[71] H. Qian, T. Zhang, Z. Yin, Q. Wang, Q. Yuan, R. Jiang, S. Yan, X. Zhao, J. Organomet. Chem. 2016, 824, 124.

[72] R. Hashemi Fath, S. J. Hoseini, J. Organomet. Chem. 2017, 828, 16.

Table 1. Spectroscopic data for compounds $S_{1}, S_{2}, Y_{1}, Y_{2}$ and 3-6

\begin{tabular}{lllll}
\hline Compound & IR; $v(\mathrm{CO}) \mathrm{cm}^{-1}$ & $\begin{array}{l}{ }^{1} \mathrm{H} \text { NMR; } \\
\delta(\mathrm{PCH}) \mathrm{ppm}\end{array}$ & $\begin{array}{l}{ }^{13} \mathrm{C} \mathrm{NMR} ; \\
\delta(\mathrm{CO}) \mathrm{ppm}\end{array}$ & $\begin{array}{l}{ }^{31} \mathrm{P} \mathrm{NMR;}(\mathrm{PCH}) \\
\text { and }\left(\mathrm{PPh}_{2}\right) \mathrm{ppm}\end{array}$ \\
\hline $\mathbf{S}_{\mathbf{1}}$ & 1676 & 5.96 & 191.40 & $21.12,-28.67$ \\
$\mathbf{S}_{\mathbf{2}}$ & 1682 & 6.08 & 191.66 & $24.41,-25.83$ \\
$\mathbf{Y}_{\mathbf{1}}$ & 1572 & 4.31 & 183.07 & $14.53,-26.82$ \\
$\mathbf{Y}_{\mathbf{2}}$ & 1572 & 4.33 & 183.18 & $15.35,-26.48$ \\
$\mathbf{3}$ & 1619 & 6.02 & 195.80 & $38.04,26.73$ \\
$\mathbf{4}$ & 1620 & 6.03 & 196.12 & $37.66,27.51$ \\
$\mathbf{5}$ & 1634 & 5.56 & 194.47 & $41.14,3.91$ \\
$\mathbf{6}$ & 1601 & 5.58 & 197.17 & $39.62,2.00$ \\
\hline
\end{tabular}

This article is protected by copyright. All rights reserved. 


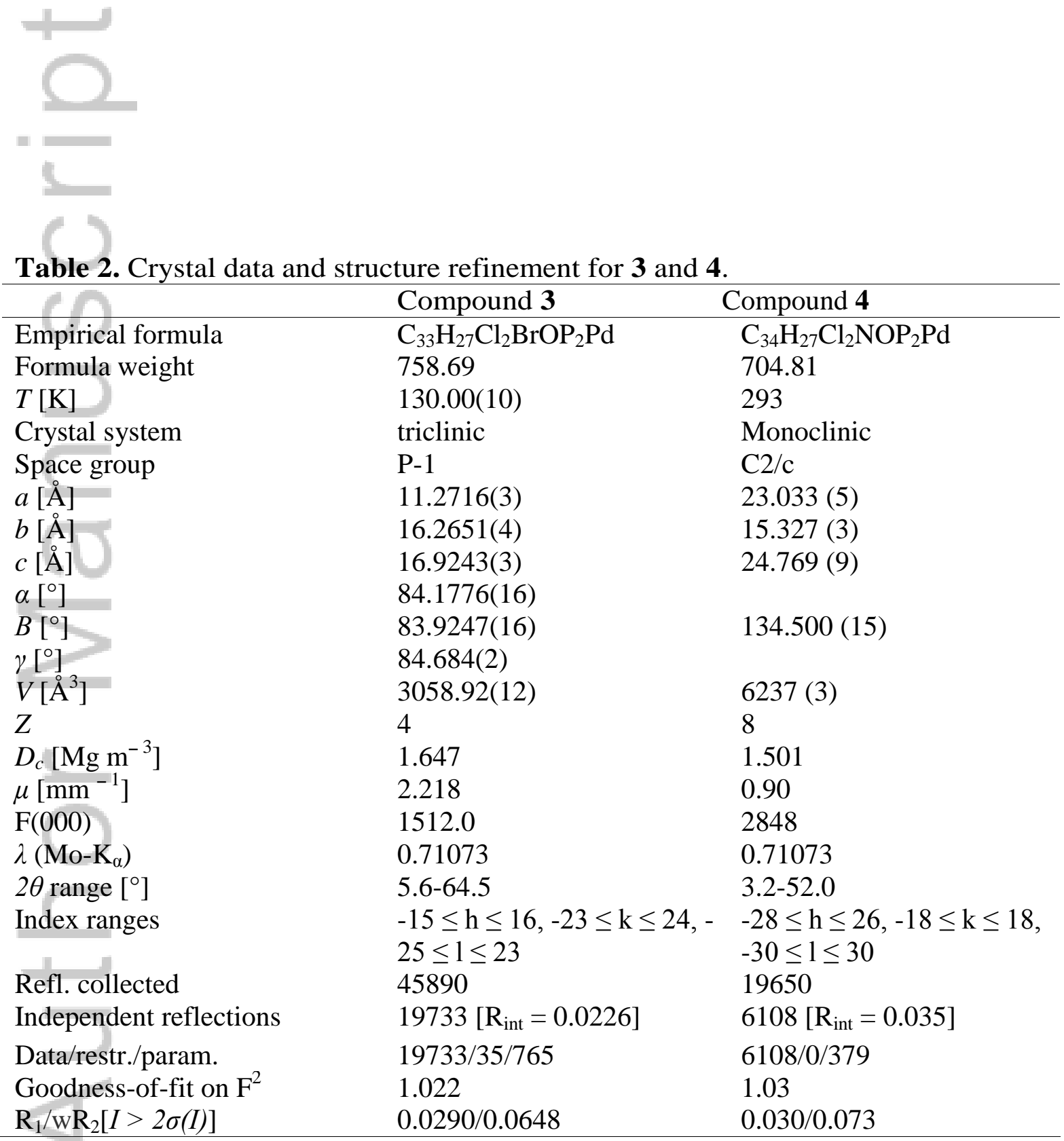

This article is protected by copyright. All rights reserved. 


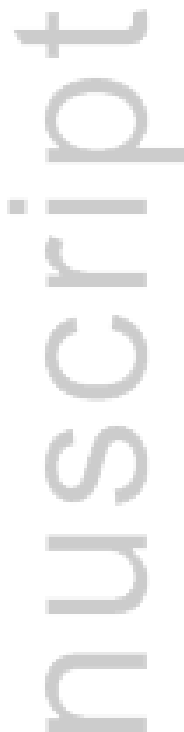

Table 3. Selected bond lengths $[\check{A}]$ and bond angles $\left[{ }^{\circ}\right]$ for $\mathbf{3}$ and 4.

\begin{tabular}{llll}
\hline & Compound 3 & & Compound 4 \\
\hline Bond distances & & & \\
Pd1-C11 & $2.3756(4)$ & Pd1-Cl1 & $2.3747(7)$ \\
Pd1-Cl2 & $2.3383(4)$ & Pd1-Cl2 & $2.3477(7)$ \\
Pd1-P2 & $2.2153(5)$ & Pd1-P1 & $2.2341(6)$ \\
Pd1-C1 & $2.1075(17)$ & Pd1-C2 & $2.095(2)$ \\
O1-C2 & $1.228(2)$ & O1-C3 & $1.231(3)$ \\
C1-C2 & $1.496(3)$ & C2-C3 & $1.486(3)$ \\
P1-C1 & $1.7817(17)$ & P2-C2 & $1.787(2)$ \\
P2-C21 & $1.8442(17)$ & P1-C1 & $1.866(2)$ \\
Bond angles & & & \\
C12-Pd1-C11 & $92.509(16)$ & C12-Pd1-Cl1 & $92.71(3)$ \\
C1-Pd1-P2 & $89.90(5)$ & C2-Pd1-P1 & $88.70(6)$ \\
C1-Pd1-C11 & $91.10(5)$ & C2-Pd1-Cl1 & $91.16(7)$ \\
P2-Pd1-Cl1 & $170.607(18)$ & P1-Pd1-Cl1 & $170.97(2)$ \\
P2-Pd1-C12 & $87.343(16)$ & P1-Pd1-Cl2 & $88.37(3)$ \\
\hline
\end{tabular}




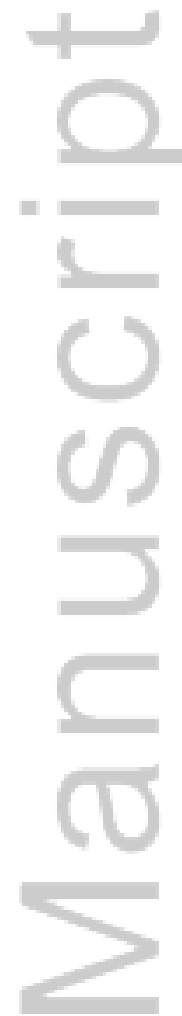

Table 4. Selected bond lengths $\left(\mathrm{A}^{\circ}\right)$ and bond angles $\left(^{\circ}\right)$ of $\left[\mathrm{Y}_{1} \mathrm{PtCl}_{2}\right]$ and $\left[\mathrm{Y}_{2} \mathrm{PtCl}_{2}\right]$ complexes at the BP86/def2-SVP level of theory.

\begin{tabular}{llllc}
\hline \multicolumn{2}{c}{$\left[\mathrm{Y}_{1} \mathrm{PtCl}_{2}\right]$} & \multicolumn{1}{c}{$\left[\mathrm{Y}_{2} \mathrm{PtCl}_{2}\right]$} & & $\begin{array}{c}{\left[\left(\mathrm{Ph}_{2} \mathrm{P}\left(\mathrm{CH}_{2}\right)_{2} \mathrm{PPh}_{2}\right.\right.} \\
\left.\left.\mathrm{CHC}(\mathrm{O}) \mathrm{CH}_{3}\right) \mathrm{PtCl}_{2}\right]^{\mathrm{a}}\end{array}$ \\
\hline Bond Lengths & Value & Bond Lengths & Value & Value \\
\hline $\mathrm{Pt}(63)-\mathrm{P}(1)$ & 2.241 & $\mathrm{Pt}(63)-\mathrm{P}(1)$ & 2.242 & 2.352 \\
$\mathrm{Pt}(63)-\mathrm{C}(14)$ & 2.117 & $\mathrm{Pt}(63)-\mathrm{C}(14)$ & 2.117 & 2.121 \\
$\mathrm{Pt}(63)-\mathrm{Cl}(65)$ & 2.399 & $\mathrm{Pt}(63)-\mathrm{Cl}(65)$ & 2.399 & 2.461 \\
$\mathrm{Pt}(63)-\mathrm{Cl}(64)$ & 2.385 & $\mathrm{Pt}(63)-\mathrm{Cl}(64)$ & 2.385 & 2.454 \\
\hline Bond angles & Value & Bond angles & Value & Value \\
\hline $\mathrm{Cl}(65)-\mathrm{Pt}(63)-\mathrm{P}(1)$ & 172.23 & $\mathrm{Cl}(65)-\mathrm{Pt}(63)-\mathrm{P}(1)$ & 171.19 & 174.84 \\
$\mathrm{Cl}(64)-\mathrm{Pt}(63)-\mathrm{C}(14)$ & 175.95 & $\mathrm{Cl}(64)-\mathrm{Pt}(63)-\mathrm{C}(14)$ & 176.40 & 170.98 \\
\hline
\end{tabular}

This article is protected by copyright. All rights reserved. 


\begin{tabular}{|c|c|c|c|c|}
\hline $\mathrm{C}(14)-\mathrm{Pt}(63)-\mathrm{P}(1)$ & 90.922 & $\mathrm{C}(14)-\mathrm{Pt}(63)-\mathrm{P}(1)$ & 91.32 & 97.67 \\
\hline $\mathrm{Cl}(64)-\mathrm{Pt}(63)-\mathrm{Cl}(65)$ & 91.614 & $\mathrm{Cl}(64)-\mathrm{Pt}(63)-\mathrm{Cl}(65)$ & 91.46 & 91.09 \\
\hline
\end{tabular}

${ }^{\mathrm{a}}$ See reference [55].

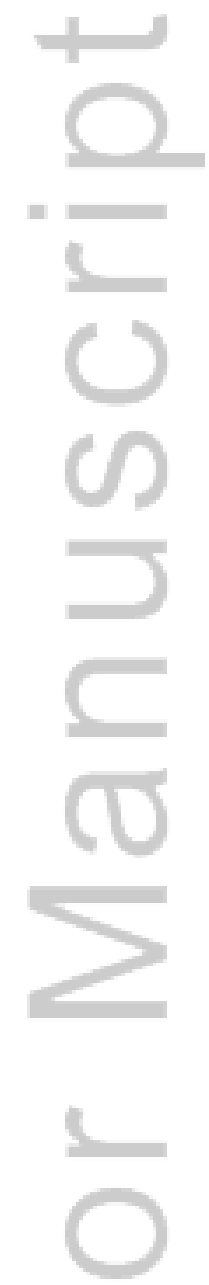

Table 5. Wiberg bond indices(WBI) of $\mathrm{Pt}-\mathrm{C}$ and $\mathrm{Pt}-\mathrm{Cl}$ bonds and natural charges of $\mathrm{Pt}, \mathrm{C}$ and $\mathrm{Cl}$ atoms as well as total charge of $\mathrm{Y}_{1}$ and $\mathrm{Y}_{2}$ fragments bonds in the complexes studied here at BP86/def2-SVP level of theory.

\begin{tabular}{cccc}
\hline & & {$\left[\mathbf{Y}_{\mathbf{1}} \mathbf{P t C l} \mathbf{I}_{\mathbf{2}}\right]$} & {$\left[\mathbf{Y}_{\mathbf{2}} \mathbf{P t C l} \mathbf{P}_{\mathbf{2}}\right]$} \\
\hline & $\mathrm{Pt}-\mathrm{C}$ & 0.49 & 0.49 \\
WBIs & $\mathrm{Pt}-\mathrm{Cl}$ & 0.71 & 0.71 \\
\hline
\end{tabular}




\begin{tabular}{cccc}
\hline & & & \\
\multirow{4}{*}{ NPA } & Pt & -0.015 & -0.013 \\
& $\mathrm{C}$ & -0.88 & -0.88 \\
& $\mathrm{P}$ & $1.58(1.14)$ & $1.59(1.14)$ \\
& $\mathrm{Y} 1$ & 0.85 & - \\
\hline & $\mathrm{Y}_{2}$ & - & 0.85 \\
\hline
\end{tabular}

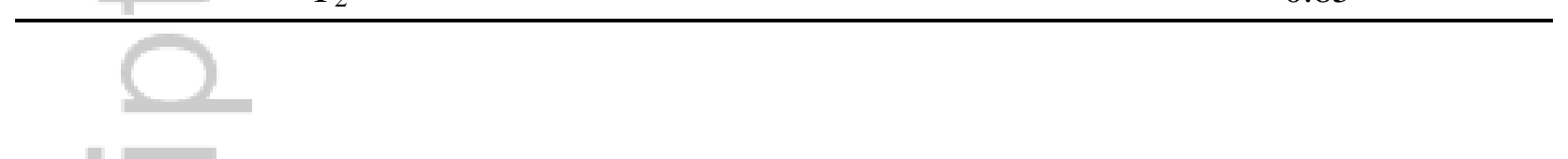

3

()

$\infty$

D

ב

(0)

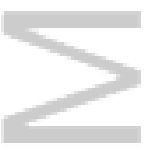

e.

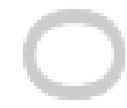

(2)

$+$

$\longrightarrow$

1

This article is protected by copyright. All rights reserved. 
Table 6. The most important donor $\rightarrow$ acceptor interactions energy concern to $\mathrm{Pt}-\mathrm{C}$ bonds in the complexes studied here at BP86/def2-SVP level of theory.

\begin{tabular}{lllll}
\hline Donor & Acceptor & Type & $\begin{array}{l}\mathbf{E}^{\mathbf{2}}(\mathbf{k c a l} / \mathbf{m o l}) \\
{\left[\mathrm{Y}_{1} \mathrm{PtCl}_{2}\right]}\end{array}$ & $\begin{array}{l}\mathbf{E}^{\mathbf{2}}(\mathbf{k c a l} / \mathbf{m o l}) \\
{\left[\mathrm{Y}_{2} \mathrm{PtCl}_{2}\right]}\end{array}$ \\
\hline $\mathrm{P}(1)-\operatorname{Pt}(63)$ & $\mathrm{Pt}(63)$ & $\sigma \rightarrow \mathrm{Lp}^{*}$ & 4.18 & 4.29 \\
\hline $\mathrm{P}(1)-\mathrm{Pt}(63)$ & $\mathrm{P}(1)-\mathrm{Pt}(63)$ & $\sigma \rightarrow \sigma^{*}$ & 9.78 & 9.98 \\
\hline $\mathrm{P}(1)-\mathrm{Pt}(63)$ & $\mathrm{C}(14)-\mathrm{Pt}(63)$ & $\sigma \rightarrow \sigma^{*}$ & 30.27 & 30.40 \\
\hline $\mathrm{C}(14)-\mathrm{Pt}(63)$ & $\mathrm{Pt}(63)$ & $\sigma \rightarrow \mathrm{Lp}^{*}$ & 10.72 & 10.76 \\
\hline $\mathrm{C}(14)-\mathrm{Pt}(63)$ & $\mathrm{P}(1)-\mathrm{Pt}(63)$ & $\sigma \rightarrow \sigma^{*}$ & 34.53 & 34.42 \\
\hline $\mathrm{C}(14)-\mathrm{Pt}(63)$ & $\mathrm{P}(2)-\mathrm{C}(8)$ & $\sigma \rightarrow \sigma^{*}$ & 18.64 & 18.83 \\
\hline $\mathrm{C}(14)-\mathrm{Pt}(63)$ & $\mathrm{C}(14)-\mathrm{C}(16)$ & $\sigma \rightarrow \sigma^{*}$ & 10.33 & 10.67 \\
\hline
\end{tabular}

This article is protected by copyright. All rights reserved. 
Table 7. EDA analysis (BP86/TZ2P(ZORA)//BP86/def2-SVP) of $\left[\mathrm{Y}_{1} \mathrm{PtCl}_{2}\right]$ and $\left[\mathrm{Y}_{2} \mathrm{PtCl}_{2}\right]$ complexes with the $\mathrm{C} 1$ symmetry.

\begin{tabular}{cccccc}
\hline $\begin{array}{c}\text { Compound } \\
\text { name }\end{array}$ & $\Delta \mathrm{E}(\text { int })^{\mathrm{a}}$ & $\Delta \mathrm{E}($ pauli $)$ & $\Delta \mathrm{E}($ elstate $)$ & $\Delta \mathrm{E}($ orb $)$ & $\Delta \mathrm{E}($ disp $)$ \\
\hline$\left[\mathrm{Y}_{1} \mathrm{PtCl}_{2}\right]$ & -156.81 & 350.87 & $-295.40(58.18)$ & $-188.43(37.14)$ & $-23.85(4.7)$ \\
{$\left[\mathrm{Y}_{2} \mathrm{PtCl}_{2}\right]$} & -153.80 & 351.59 & $-295.11(58.16)$ & $-188.39(37.13)$ & $-23.88(4.7)$ \\
\hline
\end{tabular}

${ }^{\mathrm{a}}$ The value in parenthesis gives the percentage contribution to the total orbital interactions $\Delta \mathrm{E}($ orb)

This article is protected by copyright. All rights reserved. 
Table 8. Optimizations for the Suzuki-Miyaura coupling reaction ${ }^{\mathrm{a}}$

\begin{tabular}{|c|c|c|c|c|c|}
\hline Entry & Base & Solvent & $\begin{array}{l}\text { Catalyst loading } \\
\text { (mmol) }\end{array}$ & $\begin{array}{l}\text { Temp. } \\
\left({ }^{\circ} \mathrm{C}\right)\end{array}$ & Yield $(\%)^{b}$ \\
\hline 1 & $\mathrm{~K}_{3} \mathrm{PO}_{4}$ & $\mathrm{DMF} / \mathrm{H}_{2} \mathrm{O}$ & 0.05 & 110 & 70 \\
\hline 2 & $\mathrm{~K}_{2} \mathrm{CO}_{3}$ & $\mathrm{DMF} / \mathrm{H}_{2} \mathrm{O}$ & 0.05 & 110 & 77 \\
\hline 3 & $\mathrm{NEt}_{3}$ & $\mathrm{DMF} / \mathrm{H}_{2} \mathrm{O}$ & 0.05 & 110 & 58 \\
\hline 4 & $\mathrm{~K}_{3} \mathrm{PO}_{4}$ & Methanol/ $/ \mathrm{H}_{2} \mathrm{O}$ & 0.05 & 70 & 47 \\
\hline 5 & $\mathrm{~K}_{2} \mathrm{CO}_{3}$ & Methanol/ $/ \mathrm{H}_{2} \mathrm{O}$ & 0.05 & 70 & 51 \\
\hline 6 & $\mathrm{NEt}_{3}$ & Methanol/ $\mathrm{H}_{2} \mathrm{O}$ & 0.05 & 70 & 45 \\
\hline 7 & $\mathrm{~K}_{3} \mathrm{PO}_{4}$ & Toluene $/ \mathrm{H}_{2} \mathrm{O}$ & 0.05 & 90 & 54 \\
\hline 8 & $\mathrm{~K}_{2} \mathrm{CO}_{3}$ & Toluene $/ \mathrm{H}_{2} \mathrm{O}$ & 0.05 & 90 & 35 \\
\hline 9 & $\mathrm{NEt}_{3}$ & Toluene $/ \mathrm{H}_{2} \mathrm{O}$ & 0.05 & 90 & 40 \\
\hline 10 & $\mathrm{~K}_{2} \mathrm{CO}_{3}$ & $\mathrm{H}_{2} \mathrm{O}$ & 0.05 & 100 & 44 \\
\hline 11 & $\mathrm{~K}_{2} \mathrm{CO}_{3}$ & DMF & 0.05 & 130 & 61 \\
\hline 12 & $\mathrm{~K}_{2} \mathrm{CO}_{3}$ & $\mathrm{DMF} / \mathrm{H}_{2} \mathrm{O}$ & 0.005 & 110 & 70 \\
\hline 13 & $\mathrm{~K}_{2} \mathrm{CO}_{3}$ & $\mathrm{DMF} / \mathrm{H}_{2} \mathrm{O}$ & 0.0005 & 110 & 32 \\
\hline 14 & $\mathrm{~K}_{2} \mathrm{CO}_{3}$ & $\mathrm{DMF} / \mathrm{H}_{2} \mathrm{O}$ & None & 110 & - \\
\hline 15 & $\mathrm{~K}_{2} \mathrm{CO}_{3}$ & $\mathrm{DMF} / \mathrm{H}_{2} \mathrm{O}$ & 0.1 & 110 & 92 \\
\hline 16 & $\mathrm{~K}_{2} \mathrm{CO}_{3}$ & $\mathrm{DMF} / \mathrm{H}_{2} \mathrm{O}$ & 0.005 & 65 & 58 \\
\hline 17 & $\mathrm{~K}_{2} \mathrm{CO}_{3}$ & $\mathrm{DMF} / \mathrm{H}_{2} \mathrm{O}$ & 0.005 & 25 & 40 \\
\hline
\end{tabular}

This article is protected by copyright. All rights reserved. 


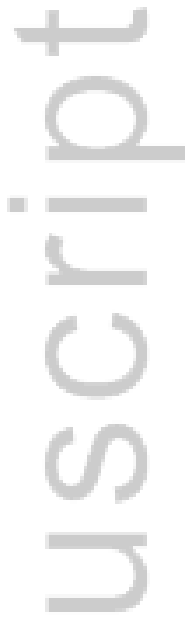

Table 9. Suzuki-Miyaura coupling reaction of aryl chlorides catalyzed by palladacycles $\mathbf{3}$ and $\mathbf{4}^{\mathrm{a}}$

\begin{tabular}{lllll}
\hline & & & \\
\hline
\end{tabular}

This article is protected by copyright. All rights reserved. 
${ }^{a}$ Reaction conditions for Suzuki-Miyaura coupling reaction: aryl chloride $(0.5 \mathrm{mmol})$, arylboronic acid $(0.75 \mathrm{mmol}), \mathrm{K}_{2} \mathrm{CO}_{3}(1 \mathrm{mmol}), \mathrm{DMF} / \mathrm{H}_{2} \mathrm{O}(2 \mathrm{~mL})$, catalyst 3 or $4(0.005$ $\mathrm{mmol})$, in the air.

${ }^{\mathrm{b}}$ Isolated yields for coupling reactions in presence of palladacycles $\mathbf{3}$ and $\mathbf{4}$, respectively.

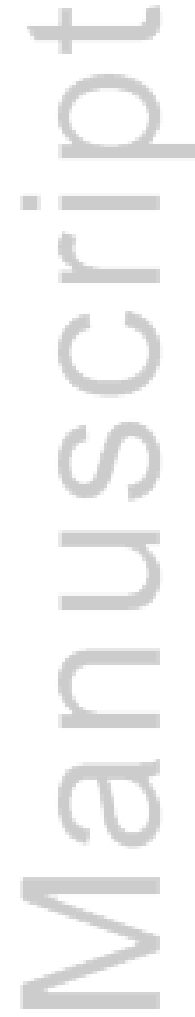

Table 10. Comparison of Suzuki-Miyaura coupling reaction of chlorobenzene and phenylboronic acid using palladacycle $\mathbf{3}$ and other catalytic systems.

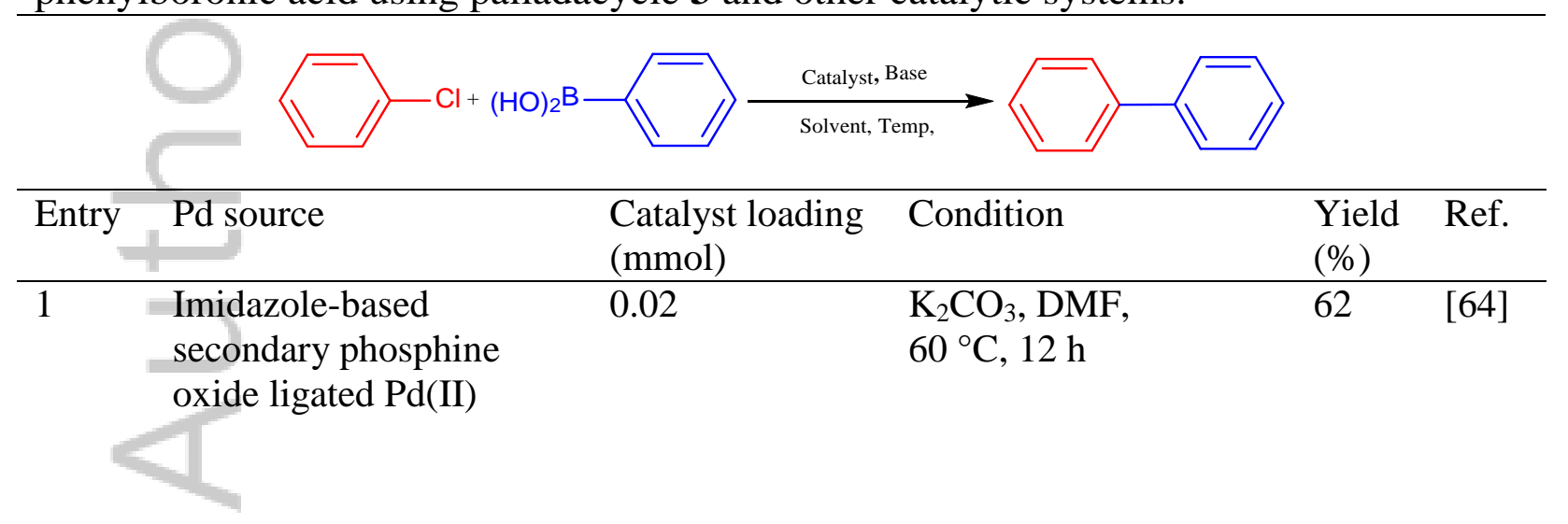

This article is protected by copyright. All rights reserved. 


\begin{tabular}{|c|c|c|c|c|c|}
\hline 2 & $\begin{array}{l}\text { Poly(N,N-dipyrid-2-yl- } \\
\text { endo-norborn-2-ene-5- } \\
\text { carbamide) based Pd(II) }\end{array}$ & 0.007 & $\begin{array}{l}\mathrm{K}_{2} \mathrm{CO}_{3}, \mathrm{DMAc} / \mathrm{TBAB}, \\
140{ }^{\circ} \mathrm{C}, 90 \mathrm{~h}\end{array}$ & 89 & [65] \\
\hline 3 & $\begin{array}{l}\text { 2,6-Bis } \\
\text { (diphenylphosphino) } \\
\text { pyridine/Pd(II) }\end{array}$ & 0.001 & $\begin{array}{l}\mathrm{K}_{2} \mathrm{CO}_{3}, \mathrm{DMAc} / \mathrm{TBAB}, \\
135^{\circ} \mathrm{C}, 5 \mathrm{~h}\end{array}$ & 57 & [66] \\
\hline 4 & $\begin{array}{l}\text { Polymer-anchored Schiff } \\
\text { base Pd(II) }\end{array}$ & 0.005 & $\begin{array}{l}\mathrm{K}_{2} \mathrm{CO}_{3}, \mathrm{DMF} \\
100{ }^{\circ} \mathrm{C}, 24 \mathrm{~h}\end{array}$ & 12 & [67] \\
\hline 5 & $\begin{array}{l}\text { 1,3-Dimesitylimidazol-2- } \\
\text { ylidene PEPPSI-type } \\
\text { Pd(II) }\end{array}$ & 0.001 & $\begin{array}{l}\mathrm{Na}_{2} \mathrm{CO}_{3}, \mathrm{EtOH} / \mathrm{CHCl}_{3}, \\
\mathrm{TBAB}, 80^{\circ} \mathrm{C}, 16 \mathrm{~h}\end{array}$ & 2 & [68] \\
\hline 6 & $\begin{array}{l}\text { Amino acid-derived } \\
\text { PEPPSI-NHC Pd(II) }\end{array}$ & 0.01 & $\begin{array}{l}\mathrm{K}_{2} \mathrm{CO}_{3}, \mathrm{H}_{2} \mathrm{O} / \mathrm{TBAB} \\
60{ }^{\circ} \mathrm{C}, 24 \mathrm{~h}\end{array}$ & 11 & [69] \\
\hline 7 & $\begin{array}{l}\text { N-heterocyclic carbene- } \\
\text { Pd(II)-pyridine (PEPPSI) }\end{array}$ & 0.01 & $\begin{array}{l}\mathrm{K}_{2} \mathrm{CO}_{3}, \mathrm{DMF} / \mathrm{H}_{2} \mathrm{O}, \\
80{ }^{\circ} \mathrm{C}, 3 \mathrm{~h}\end{array}$ & 85 & [70] \\
\hline 8 & $\begin{array}{l}\text { Ferrocene tertiary amine } \\
\text { palladacycle }\end{array}$ & 0.02 & $\begin{array}{l}\mathrm{K}_{3} \mathrm{PO}_{4}, \text { Toluene, } \\
60^{\circ} \mathrm{C}, 8 \mathrm{~h}\end{array}$ & 60 & [71] \\
\hline 9 & $\begin{array}{l}\text { 2-Phenylpyridine/DMSO } \\
\text { palladacycle }\end{array}$ & 0.1 & $\begin{array}{l}\mathrm{K}_{2} \mathrm{CO}_{3} \text {, Toluene, } \\
25^{\circ} \mathrm{C}, 2 \mathrm{~h}\end{array}$ & 65 & [72] \\
\hline 10 & $\begin{array}{l}\text { P, C-chelated } \\
\text { phosphorus ylide Pd(II) }\end{array}$ & 0.005 & $\begin{array}{l}\mathrm{K}_{2} \mathrm{CO}_{3}, \mathrm{DMF} / \mathrm{H}_{2} \mathrm{O} \\
110^{\circ} \mathrm{C}, 6 \mathrm{~h}\end{array}$ & 70 & $\begin{array}{l}\text { This } \\
\text { work }\end{array}$ \\
\hline
\end{tabular}

This article is protected by copyright. All rights reserved. 


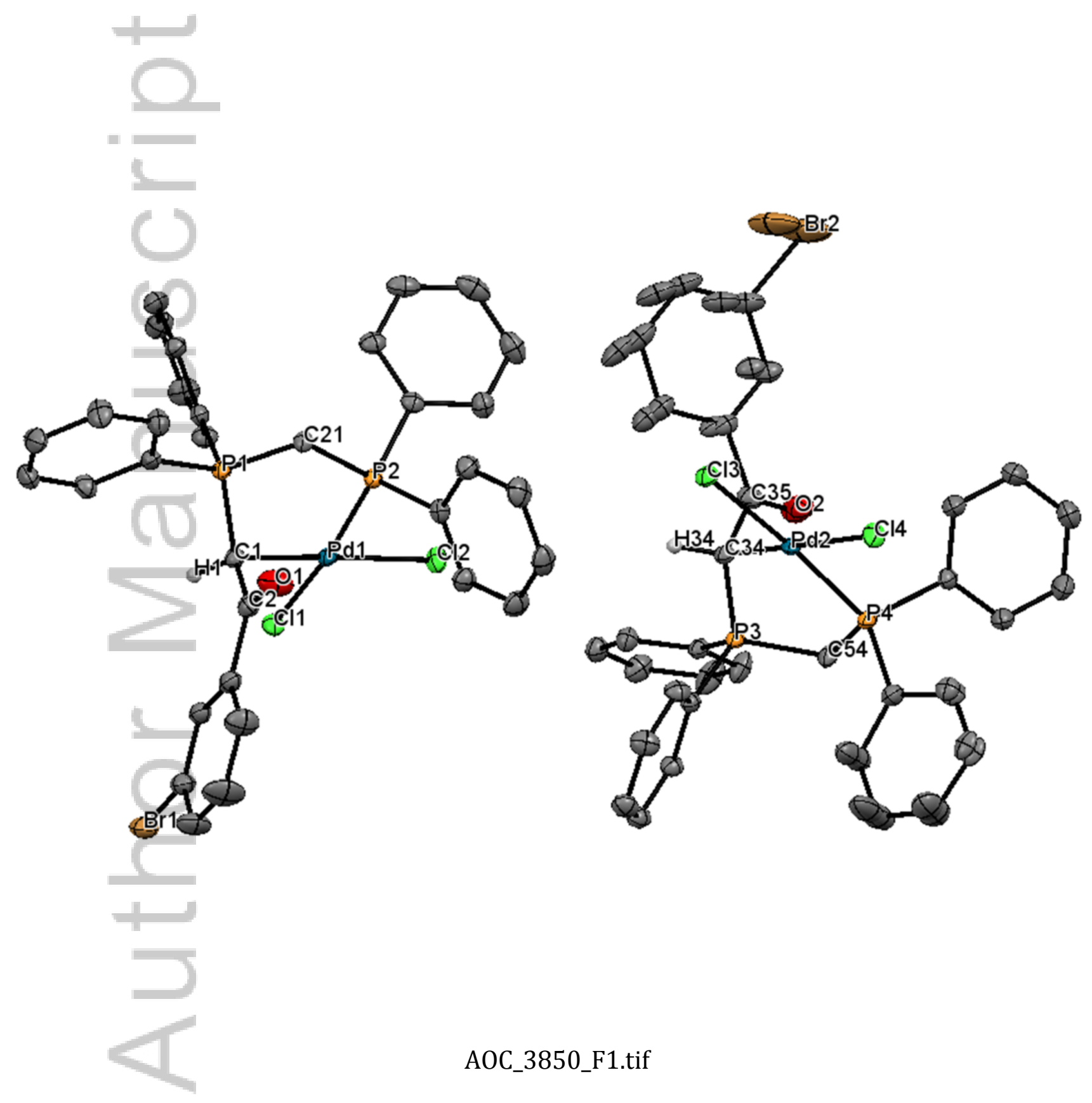

This article is protected by copyright. All rights reserved. 

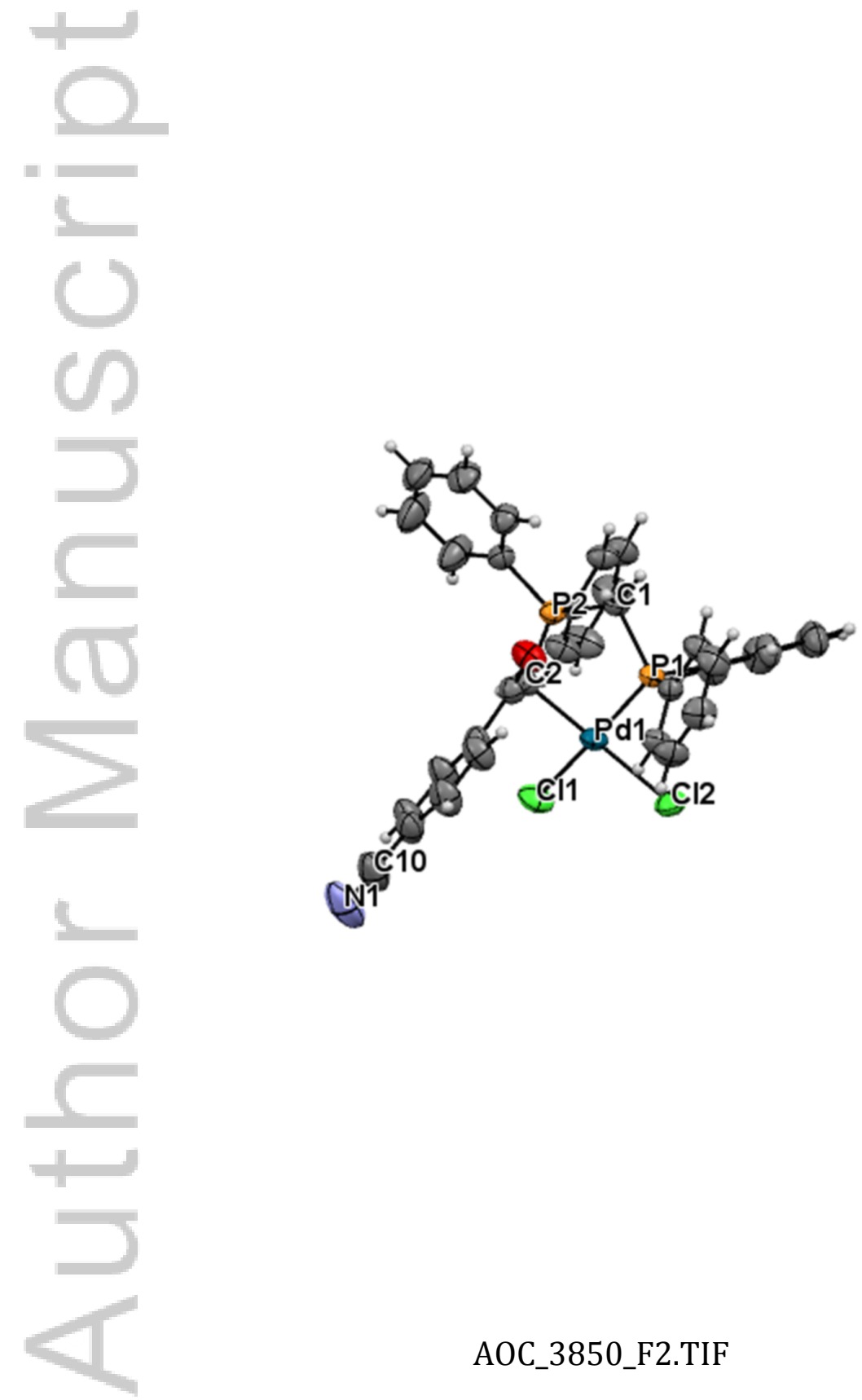

AOC_3850_F2.TIF

This article is protected by copyright. All rights reserved. 


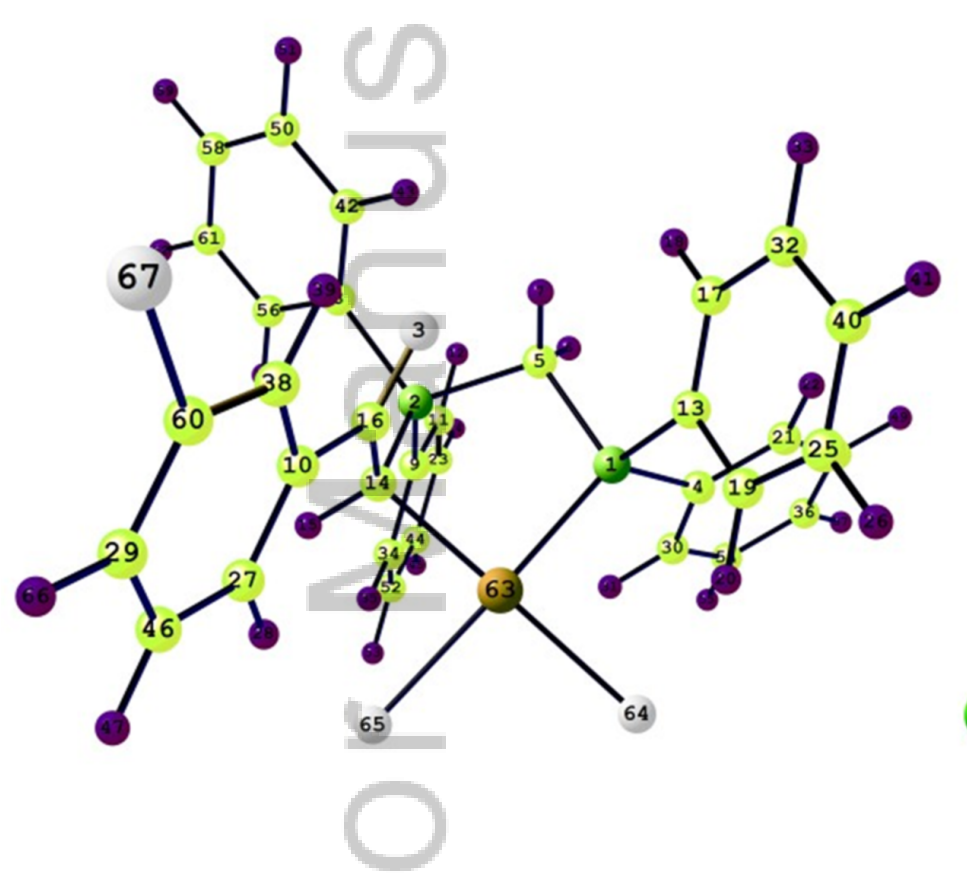

3a

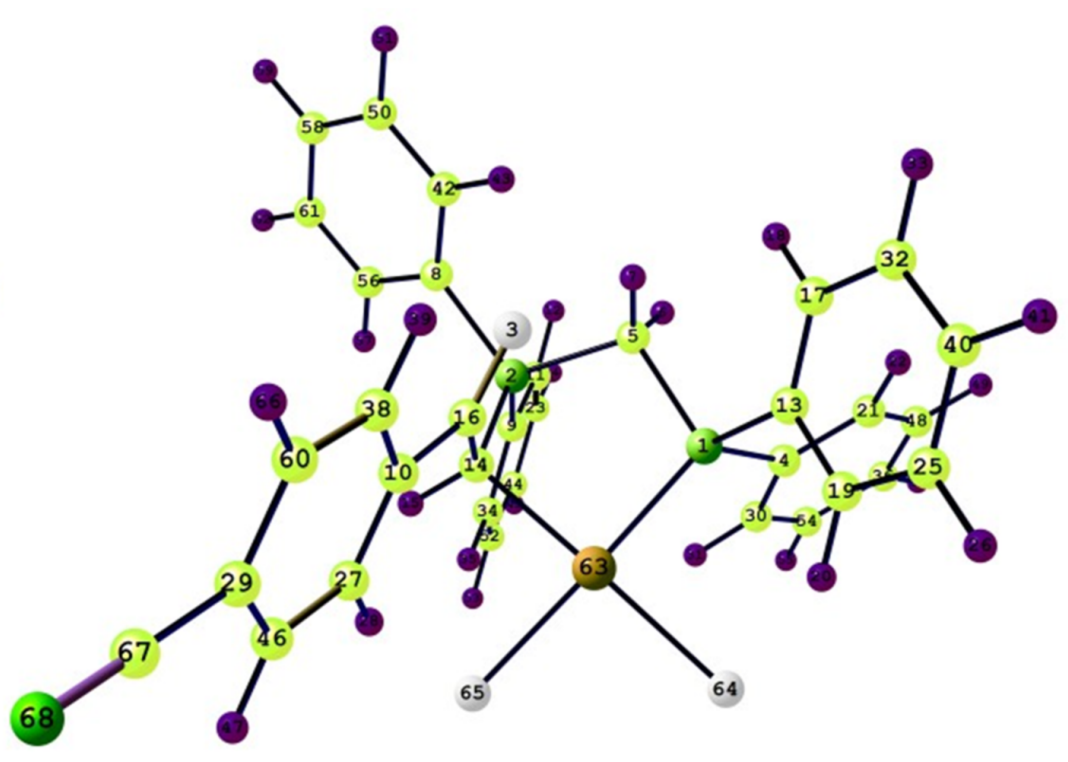

3b

AOC_3850_F3.TIF

This article is protected by copyright. All rights reserved. 


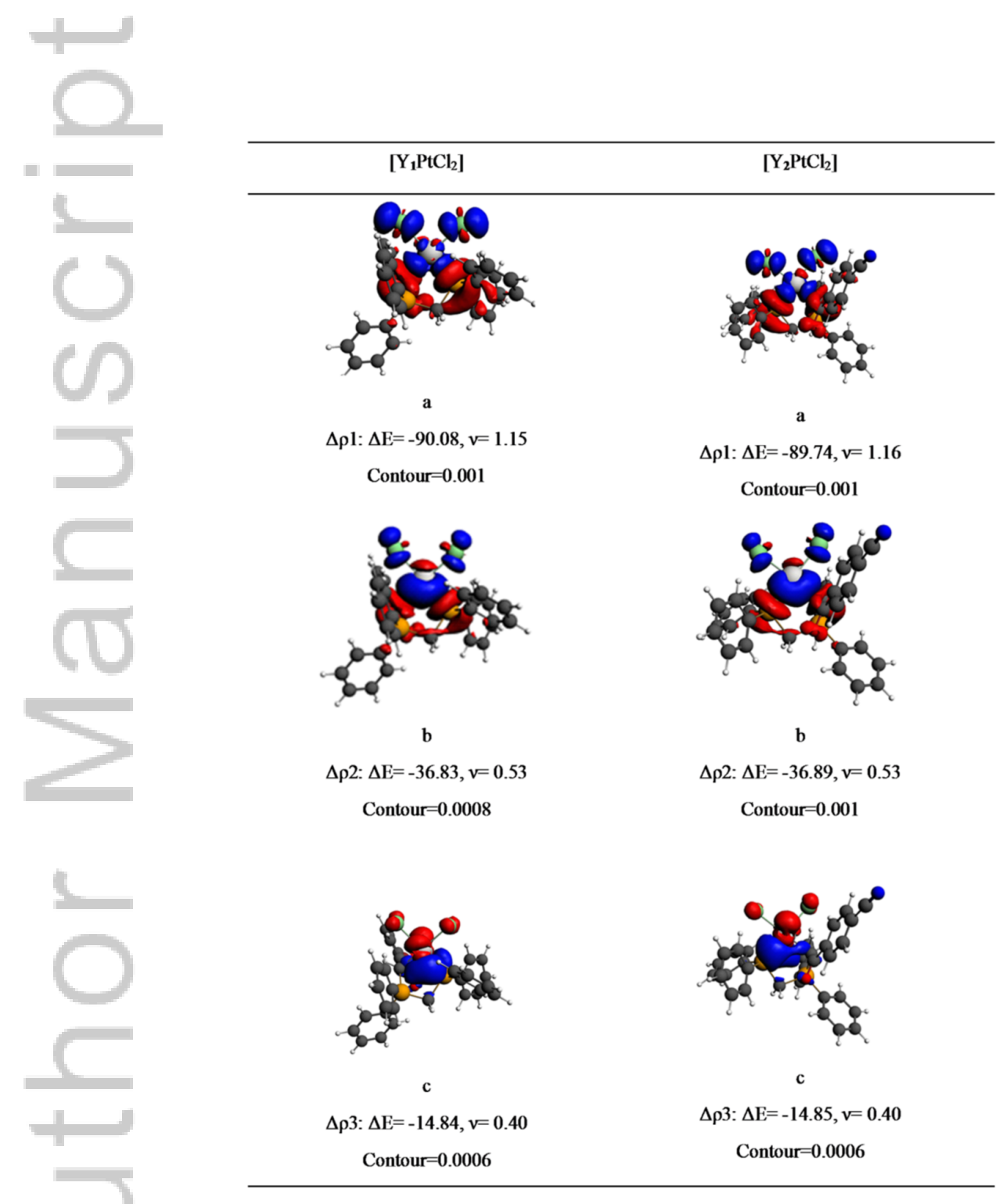

AOC_3850_F4.tif

This article is protected by copyright. All rights reserved. 

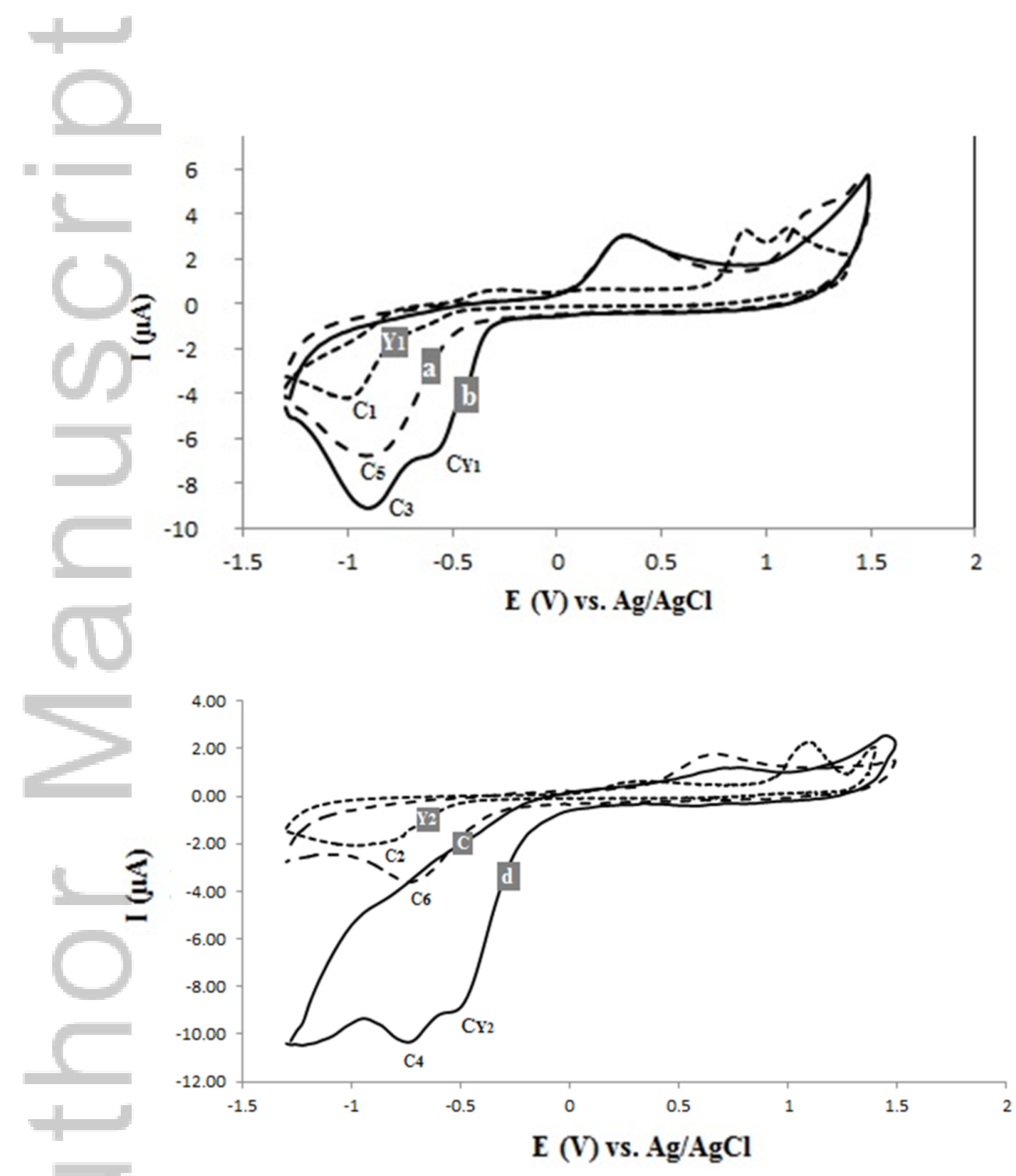

AOC_3850_F5.TIF

This article is protected by copyright. All rights reserved. 


\section{Table of Contents Entry}

\section{Pallada- and platinacycle complexes of phosphorus ylides; Synthesis, X-ray characterization, theoretical and electrochemical studies and application of Pd(II) complexes as catalyst in Suzuki-Miyaura coupling reaction}

Seyyed Javad Sabounchei ${ }^{\mathrm{a}^{*}}$, Asieh Sedghi ${ }^{\mathrm{a}}$, Ali Hashemi ${ }^{\mathrm{a}}$, Marjan Hosseinzadeh ${ }^{\mathrm{a}}$, Mehdi Bayat $^{\mathrm{a}}$, Robert W. Gable ${ }^{\mathrm{b}}$

${ }^{a}$ Faculty of Chemistry, Bu-Ali Sina University, Hamedan,65174, Iran

${ }^{\mathrm{b}}$ School of Chemistry, University of Melbourne, Victoria, 3010, Australia
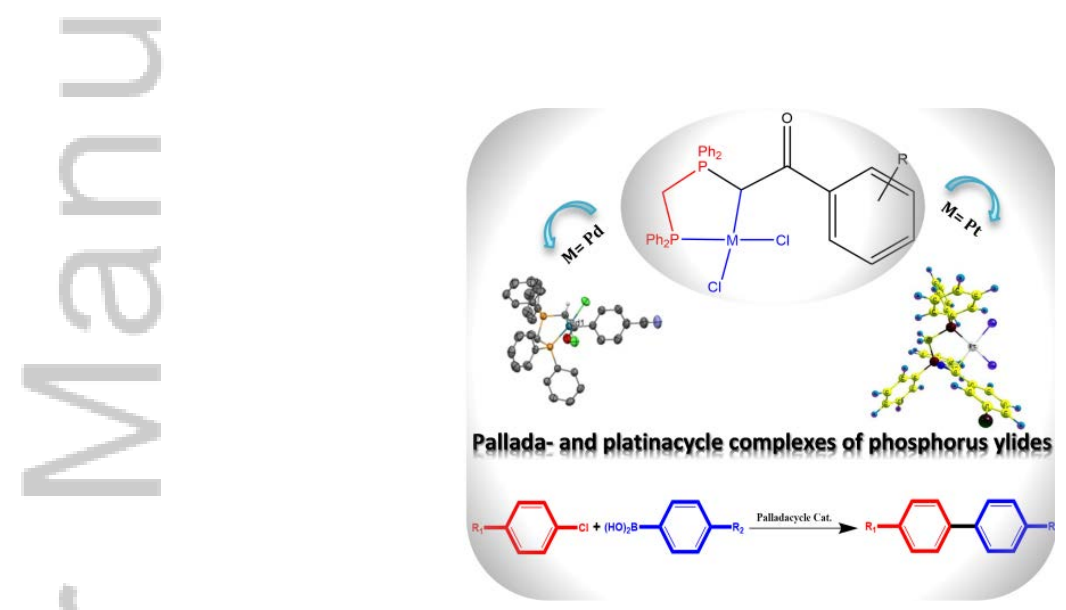

We report the synthesis and characterization of new pallada- and platinacycle complexes $\left[\mathrm{MCl}_{2}\left(\mathrm{Ph}_{2} \mathrm{PCH}_{2} \mathrm{PPh}_{2} \mathrm{C}(\mathrm{H}) \mathrm{C}(\mathrm{O}) \mathrm{C}_{6} \mathrm{H}_{4} \mathrm{R}\right)\right](\mathrm{M}=\mathrm{Pd}$ and $\mathrm{Pt}, \mathrm{R}=m-\mathrm{Br}$ and $p-\mathrm{CN})$ and application of $\mathrm{Pd}(\mathrm{II})$ complexes as catalyst in Suzuki-Miyaura coupling reaction.

\footnotetext{
*Corresponding author. E-mail address: jsabounchei@ yahoo.co.uk (S.J. Sabounchei).
} 


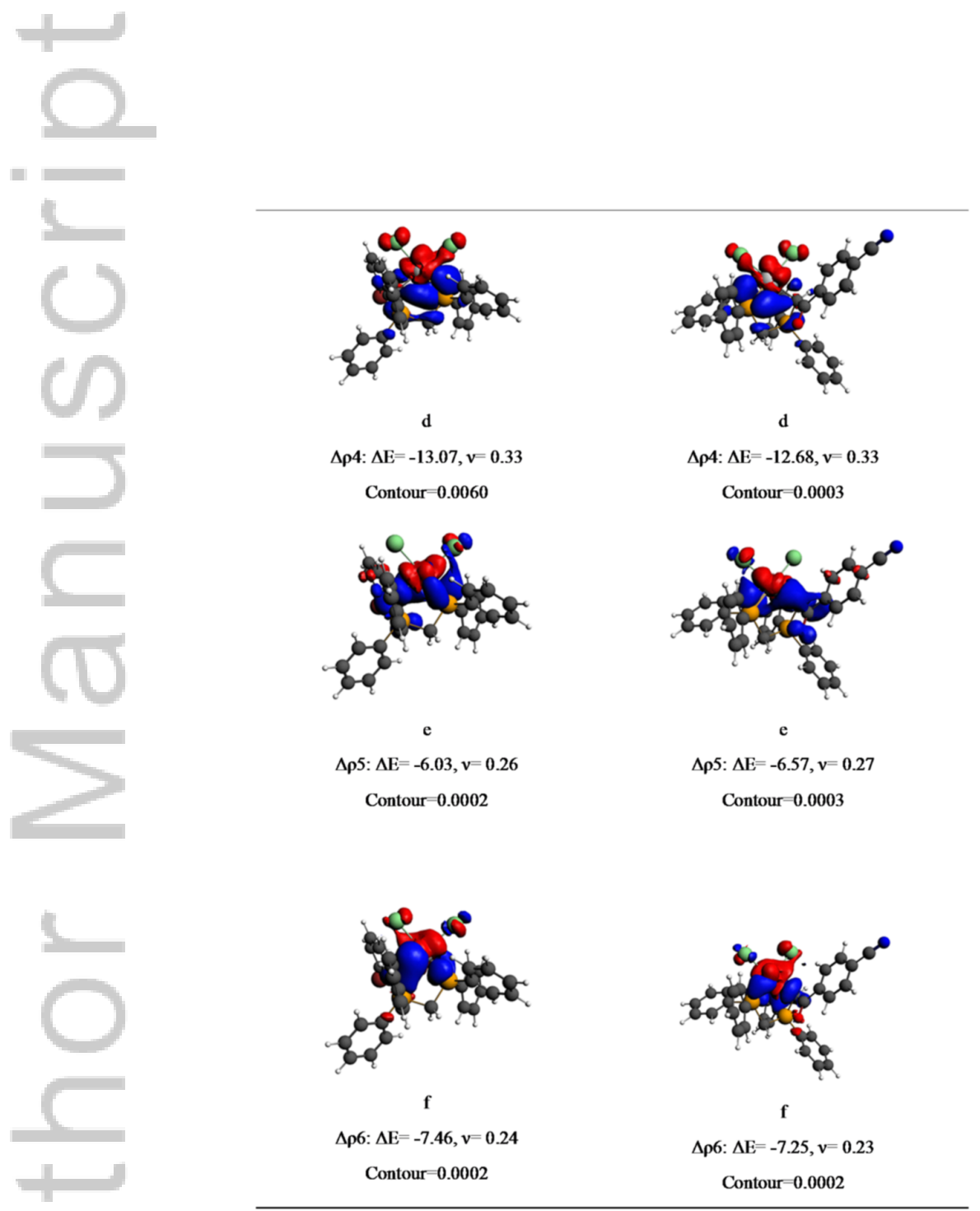

AOC_3850_Rest of Fig. 4.tif

This article is protected by copyright. All rights reserved. 


\section{University Library}

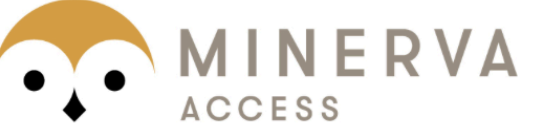

A gateway to Melbourne's research publications

Minerva Access is the Institutional Repository of The University of Melbourne

Author/s:

Sabounchei, SJ;Sedghi, A;Hashemi, A;Hosseinzadeh, M;Bayat, M;Gable, RW

Title:

Pallada- and platinacycle complexes of phosphorus ylides; synthesis, X-ray characterization, theoretical and electrochemical studies and application of Pd(II) complexes as catalyst in Suzuki-Miyaura coupling reaction

Date:

2017-12-01

Citation:

Sabounchei, S. J., Sedghi, A., Hashemi, A., Hosseinzadeh, M., Bayat, M. \& Gable, R. W. (2017). Pallada- and platinacycle complexes of phosphorus ylides; synthesis, Xray characterization, theoretical and electrochemical studies and application of $\mathrm{Pd}(\mathrm{II})$ complexes as catalyst in Suzuki-Miyaura coupling reaction. APPLIED ORGANOMETALLIC CHEMISTRY, 31 (12), https://doi.org/10.1002/aoc.3850.

Persistent Link:

http://hdl.handle.net/11343/292894 